\title{
A reappraisal of active tectonics along the Fethiye-Burdur trend, southwestern Turkey
}

Edwin Nissen ${ }^{1}$, Musavver Didem Cambaz ${ }^{2}$, Élyse Gaudreau ${ }^{1}$, Andrew Howell $^{3,4}$, Ezgi Karasözen ${ }^{5,6}$, and Elena Savidge ${ }^{1,6}$

${ }^{1}$ School of Earth and Ocean Sciences, University of Victoria, Victoria BC, Canada

${ }^{2}$ Regional Earthquake Tsunami Monitoring Center, Kandilli Observatory and Earthquake Research Institute, Boğaziçi University, 34684 Çengelköy, İstanbul, Turkey

${ }^{3}$ School of Earth and Environment, University of Canterbury, Christchurch 8140, New Zealand

${ }^{4}$ GNS Science, Lower Hutt 5040, New Zealand

${ }^{5}$ Alaska Earthquake Center, University of Alaska Fairbanks, Fairbanks, Alaska 99775, USA

${ }^{6}$ Department of Geophysics, Colorado School of Mines, Golden, Colorado 80401, USA

Received 2021 July 6; in original form 2021 July 6

This is a non-peer reviewed preprint posted to EarthArxiv. The manuscript was submitted to Geophysical Journal International on 6 July 2021, and subsequent versions may have slightly different content. The authors would welcome feedback, sent to enissen@uvic.ca. 


\section{SUMMARY}

We investigate active tectonics in southwestern Turkey along the trend between Fethiye, near the eastern end of the Hellenic subduction zone, and Burdur, on the Anatolian plateau. Previously, regional GPS velocity data have been used to propose either (1) a NE-trending zone of strike-slip faulting coined the Fethiye-Burdur Fault Zone, or (2) a mix of uniaxial and radial extension accommodated by normal faults with diverse orientations. We test these models against the available earthquake data, updated in light of recent earthquakes at Acıpayam (20 March 2019, $M_{w}$ 5.6) and Bozkurt (8 August 2019, $M_{w}$ 5.8) - the largest in this region in the last two decades - and at Arıcılar (24 November 2017, $M_{w}$ 5.3). Using Sentinel-1 InSAR and seismic waveforms and arrival times, we show that the Acıpayam, Bozkurt and Arıcilar earthquakes were buried ruptures on pure normal faults with subtle or indistinct topographic expressions. By exploiting ray paths shared with these well-recorded modern events, we relocate earlier instrumental seismicity throughout southwestern Turkey. We find that the 1971 $M_{w} 6.0$ Burdur earthquake likely ruptured a NW-dipping normal fault in an area of indistinct geomorphology near Salda Lake, contradicting earlier studies that place it on well-expressed faults bounding the Burdur basin. Overall, the northern Fethiye-Burdur trend is characterized by orthogonal normal faulting, consistent with radial extension and likely responsible for the distinct physiography of Turkey's 'Lake District'. The southern Fethiye-Burdur trend is dominated by ESE-WNW trending normal faulting, even though most faults evident in the topography strike NE-SW. This hints at a recent change in regional strain, perhaps related to eastward propagation of the Gököva graben into the area or to rapid subsidence of the Rhodes basin. Overall, our results support GPS-derived tectonic models that depict a mix of uniaxial and radial extension throughout southwestern Turkey, with no evidence for major, active strike-slip faults anywhere along the Fethiye-Burdur trend. Normal faulting orientations are consistent with a stress field driven primarily by contrasts in gravitational potential energy between the elevated Anatolian plateau and the low-lying Rhodes and Antalya basins.

Key words: Seismicity and tectonics, earthquake source observations, satellite geodesy, continental neotectonics, earthquake hazards 


\section{INTRODUCTION}

Southwestern Turkey is characterized by active crustal faulting and abundant seismicity, but the kinematics and dynamics of this deformation are both controversial. The region sits astride two arcuate, northward-dipping subduction zones - the Hellenic and Cyprus arcs — in which $\mathrm{Nu}-$ bian oceanic lithosphere is consumed beneath continental Anatolia (Figure 1). Kinematically, it is debatable whether or not the two subduction zones are linked by transform faulting across a triangular structural trend known as the 'Isparta Angle' (e.g. Glover \& Robertson 1998). Dynamically, it is unclear whether crustal deformation in this region is driven mostly by plate boundary forces (Jiménez-Munt \& Sabadini 2002; Reilinger et al. 2006), by contrasts in gravitational potential energy between thickened continental crust of the Anatolian plateau and low-lying oceanic lithosphere of the Mediterranean basin (England et al. 2016), or by a mixture of the two (Özeren \& Holt 2010). The purpose of this paper is to reexamine the western limb of the Isparta Angle, between the cities of Fethiye, on the Mediterranean coastline, and Burdur, on the Anatolian plateau. Our focus is on the kinematics of active faulting, though there are obvious implications for what is driving this deformation, which we discuss briefly toward the end of the paper.

The easternmost Hellenic subduction zone is characterized by parallel bathymetric troughs termed the Pliny and Strabo trenches, which are highly oblique to Nubia-Anatolia plate convergence and may involve some component of sinistral strike-slip faulting (McKenzie 1972; Hall et al. 2009; Shaw \& Jackson 2010; Özbakır et al. 2013). It has been proposed that these faults continue across the Rhodes Basin and into Anatolia, forming a NE-trending zone of discontinuous, sinistral or sinistral-transtensional faults known as the "Fethiye-Burdur Fault Zone" (FBFZ) (e.g. Dumont et al. 1979; Hall et al. 2014; Elitez et al. 2015, 2016, 2017; Aksoy \& Aksarı 2016). Several of these faults are included in Turkey's most recent active fault database (Emre et al. 2018). Early Global Positioning System (GPS) studies assigned the FBFZ an overall left-lateral slip-rate of $\sim 15-20 \mathrm{~mm} / \mathrm{yr}$, on the basis that sites along Turkey's Aegean coastline move more rapidly southwestwards than those along its Mediterranean coastline (Eyidogan \& Barka 1996; Barka \& Reilinger 1997). More recent block models based on densified GPS data have revised down- 
wards these displacement rates, yielding sinistral slip at $\sim 3-5 \mathrm{~mm} / \mathrm{yr}$ along the southern FBFZ and a switch to right-lateral slip at $\sim 4-11 \mathrm{~mm} / \mathrm{yr}$ along the northern FBFZ (Reilinger et al. 2006; Tiryakioğlu et al. 2013) (Figure 2a-c). However, even at these lower rates the FBFZ would count amongst the most important sources of seismic hazard in western Turkey. Furthermore, linkage between the purported FBFZ and the eastern Hellenic arc may have important implications for regional tsunami hazards (England et al. 2015; Howell et al. 2015).

However, the presence of active strike-slip faulting along the Fethiye-Burdur trend has been called into question, with several studies pointing to a dominance of extensional faulting throughout this region (e.g. Koçyiğit 2005). Reported left-lateral geological offsets have been challenged (Alçiçek 2015) and kinematic indicators on two of the most prominent NE-trending faults - those bounding the Burdur and Çameli basins — support normal motions since their inception in the late Miocene (Price \& Scott 1994; Alçiçek et al. 2006; Özkaptan et al. 2018). A paleoseismic study of another of the longest NE-trending structures through the region — the Acipayam fault — also suggested predominantly normal kinematics (Kürçer et al. 2016). Regional paleomagnetic data are also inconsistent with a major, through-going, crustal strike-slip fault (Kaymakc1 et al. 2018). Most recently, offshore seismic reflection surveys and onshore field measurements in and around the Gulf of Fethiye showed evidence only of normal faulting of a variety of orientations (Tosun et al. 2021). The geodetic evidence for NE-trending strike-slip faulting is also disputed. Aktug et al. (2009) showed that smoothed strain rate fields fit observed GPS velocities better than block models, with N-S extensional principal axes NW of the Fethiye-Burdur trend rotating to E-W extensional principal axes SE of it. A revised, smoothed strain rate field by Howell et al. (2017) shows radial divergence within the northern part of our study area, and uniaxial extension accompanied by counterclockwise vertical axis rotations further south (Figure 2d).

Earthquake focal mechanisms provide another means of assessing the importance of strike-slip faulting in southwestern Turkey (Figure 3). Most well-studied crustal earthquakes along the FethiyeBurdur trend have involved normal faulting of a variety of orientations (e.g. Taymaz \& Price 1992; 
Wright et al. 1999; Över et al. 2010, 2013, 2016; Cambaz \& Mutlu 2016; Howell et al. 2017). Largest amongst these were destructive earthquakes at Dinar in $1995\left(M_{w} 6.5\right)$, which ruptured the SW-dipping Dinar normal fault (Wright et al. 1999), and at Burdur in $1971\left(M_{w} 6.0\right)$, tentatively attributed to the NW-dipping Hacilar normal fault (Taymaz \& Price 1992) (Figures 3, 4). At the northern tip of the Isparta Angle, the 2000-2002 Sultandağı-Çay (Afyon) sequence - which included earthquakes of $M_{w}$ 6.0, 6.4 and 5.8 - involved NE-, N-, and NW-dipping normal faults (Koçyiğit \& Özacar 2003; Aksarı et al. 2010). Three large earthquakes offshore Fethiye $-M_{w} 6.8$ and 7.2 events in 1957 and a $M_{w} 6.2$ event in 2012 (Figure 3) — do have pure strike-slip mechanisms, but likely occurred within subducting Nubian lithosphere rather than within the overriding continental crust (Howell et al. 2017).

Two recent, damaging earthquakes - at Acıpayam on 20 March $2019\left(M_{w} 5.6\right)$ and at Bozkurt on 8 August $2019\left(M_{w} 5.8\right)$ - were the largest along the Fethiye-Burdur trend in more than two decades and were well-recorded by satellite-borne Interferometric Synthetic Aperture Radar (InSAR) as well as by regional and teleseismic waveforms and arrival times. A $M_{w} 5.3$ earthquake at Arıcilar on 24 November 2017 is also associated with a clear surface deformation signal in InSAR imagery. These well-recorded modern earthquake sequences provide a wealth of new data with which to reexamine the role of strike-slip faulting in regional tectonics. In Section 2, we describe the geodetic and seismological data and modelling approaches used to characterize the modern earthquakes, and discuss a catalogue of regional focal mechanisms compiled from the literature and updated with new, relocated hypocenters. In Section 3, we examine in turn the source characteristics of the March-April 2019 Acipayam sequence, the August 2019 Bozkurt sequence, and the November 2017 Arıcılar sequences. In Section 4, we reassess seismicity across the wider FethiyeBurdur trend in light of the end-member tectonic models discussed previously. This includes new constraints on the destructive 12 May $1971 M_{w} 6.0$ Burdur earthquake and discussion of a number of other important, early instrumental events. 


\section{DATA AND METHODS}

\subsection{InSAR observations and modelling}

We used European Space Agency Sentinel-1 synthetic aperture radar interferograms and elastic dislocation modelling to characterize faulting in the 2019 Acıpayam, 2019 Bozkurt and 2017 Arıcilar earthquakes. For each event we used GAMMA software to construct short (6 or 12 day) coseismic interferograms on ascending track $58 \mathrm{~A}$ and descending track $138 \mathrm{D}$, choosing in each case the earliest available post-event scene in order to minimize the contribution from postseismic deformation. For the Arıcılar earthquake, we added a third interferogram from ascending track 131A; no Sentinel-1 scenes were captured between the two earthquakes, and so each interferogram captures the coseismic deformation of both events. Radar incidence angles are between $36^{\circ}$ and $38^{\circ}$ at both the Acipayam and Bozkurt epicenters, and between $31^{\circ}$ and $43^{\circ}$ at the Aricilar epicenters.

To model the interferograms we followed the routine procedures of Wright et al. (2003), which have been deployed on several other modern earthquakes across Turkey (Taymaz et al. 2007; Elliott et al. 2013; Karasözen et al. 2016, 2018; Pousse-Beltran et al. 2020). We first downsampled the unwrapped interferograms using a Quadtree algorithm (Jónsson et al. 2002) and then solved for the fault plane parameters that minimize differences between these datapoints and synthetic displacements calculated for a rectangular fault plane embedded within an elastic half-space (Okada 1985). For the half-space, we chose Lamé parameters $\mu=3.2 \times 10^{10} \mathrm{~Pa}$ and Poisson ratio 0.25 , consistent with the velocity structure obtained and applied elsewhere in this study. We inverted for fault strike, dip, rake, uniform slip, center point, length, and top and bottom depths, as well as linear $\mathrm{N}-\mathrm{S}$ and $\mathrm{E}-\mathrm{W}$ orbital ramps and the zero displacement level. A global minimum misfit is achieved using Powell's algorithm with multiple Monte Carlo restarts (Press et al. 1992; Clarke et al. 1997; Wright et al. 1999). Having established uniform slip models for each earthquake, we extended and subdivided the model fault plane into $1 \mathrm{~km} \times 1 \mathrm{~km}$ subfaults and estimated the 
slip distribution using a Laplacian operator to force realistic slip gradients between neighboring patches (Wright et al. 2003).

\subsection{Teleseismic body waveform modelling}

We used long-period teleseismic body waveform modelling as an independent check on the source mechanisms and depths of the $M_{w} 5.6$ Acıpayam and $M_{w} 5.8$ Bozkurt mainshocks. By accounting for direct $P$ and $S$ waves and their surface-reflected depth phases $p P, s P$ and $s S$, this method can resolve centroid depths of large $\left(M_{w} \geq \sim 5.5\right)$ earthquakes to within $\sim 3-4 \mathrm{~km}$, a marked improvement on automated, global catalogs which often fix the depths of upper crustal events $a$ priori (Molnar \& Lyon-Caen 1989; Taymaz et al. 1990; Maggi et al. 2002; Wimpenny \& Watson 2021). This additional depth constraint can potentially help determine whether fault slip resolved by InSAR modelling was generated seismically or by aseismic creep (Nissen et al. 2014).

We followed the procedures outlined by Molnar \& Lyon-Caen (1989), in common with several other regional earthquake studies (e.g. Taymaz et al. 1991; Kiratzi \& Louvari 2003; Benetatos et al. 2004; Shaw \& Jackson 2010; Yolsal-Çevikbilen et al. 2014; Howell et al. 2017). For both events, we first selected waveforms recorded at distances of $30-80^{\circ}$ - avoiding complications from the core - and then filtered them using a 15-100 second bandpass, which allows the earthquakes to be treated as simple point sources. We then used the MT5 version (Zwick et al. 1994) of the weighted least squares algorithm of McCaffrey \& Abers (1988) and McCaffrey et al. (1991) to solve for the minimum misfit strike, dip, rake, centroid depth, seismic moment and source-time function of each event. These are found by minimizing residuals between observed $P$ and $S H$ waveforms and synthetic seismograms computed using $P, p P, s P, S$ and $s S$ phases of a point souce embedded within an elastic half-space. We chose $V_{P}$ as $6.0 \mathrm{~km} / \mathrm{s}, V_{S}$ as $3.5 \mathrm{~km} / \mathrm{s}$, and density as $2700 \mathrm{~kg} / \mathrm{m}^{3}$, consistent with regional constraints (see Section 2.4). For the observed $P$ and $S H$ waveforms, we used 30 second vertical component seismograms and 40 second transverse component seismograms, respectively. The synthetic waveforms were adjusted to match $P$ and $S$ arrival times picked from broadband records, and weighted by azimuthal density in the inversion. 


\section{$8 \quad$ E. Nissen et al.}

\subsection{Regional waveform modelling}

We estimated moment tensors for several additional earthquakes in the 2019 Acıpayam and Bozkurt and 2017 Arıcilar sequences by modelling regional waveforms. Having larger signal-to-noise than teleseismic waveforms, regional waveforms permitted assessment of far smaller earthquakes, down to $M_{w} 3.5$ in this study. We investigated around fifty earthquakes, of which 36 yielded robust mechanisms that meet strict quality and variance reduction criteria (Zahradník \& Sokos 2018) and which are presented here.

For each event, we gathered waveform data recorded over the distance range 50-300 km by stations belonging to several regional networks listed in the Acknowledgements. The preferred frequency band for the inversion was selected after a careful analysis of the signal-to-noise ratio and station epicentral distances, and Green's functions were estimated for the local velocity model (Section 2.4) using the discrete wavenumber method of Bouchon (1981) and Coutant (1989). We then used the iterative deconvolution inversion method of Kikuchi \& Kanamori (1991), implemented in the ISOLA software package (Sokos \& Zahradník 2008, 2013), to solve for the best point source representation of each earthquake. All but one of the events have majority doublecouple components (with half of them $>90 \%$ ) and we present here the best double-couple solutions.

Previous regional waveform modelling studies indicate that minimum misfit centroid depths can vary according to the station configurations, velocity models, and frequency bands used in the inversion (e.g. Zahradnik et al. 2008; Haddad et al. 2020). Accordingly, for a few of the critical, larger events analyzed, we repeated the inversion using perturbations to these parameters — including alternative, published regional velocity models — from which we estimated centroid depth uncertainties of $\sim 1-2 \mathrm{~km}$. However, the smaller events studied here are likely to have greater uncertainties, perhaps up to around $5 \mathrm{~km}$ (Herman et al. 2014). 


\subsection{Calibrated hypocenter relocations}

We used local, regional and teleseismic arrival times to determine calibrated hypocenters for the 2019 Acıpayam and Bozkurt and 2017 Arıcilar sequences, as well as background seismicity across southwestern Turkey. We collated phase arrival times from regional archives listed in the Acknowledgements and from the global International Seismological Centre (ISC) bulletin. The selected earthquakes were then separated into five distinct geographic clusters — one each for the Acıpayam and Bozkurt sequences, and three others centered on Çameli in the southwestern Fethiye-Burdur trend, Burdur in the northeastern Fethiye-Burdur trend, and Beyşehir in the eastern Isparta Angle (Figure 3). Finally, each cluster was relocated using the Hypocentroidal Decomposition (HD) method (Jordan \& Sverdrup 1981) as implemented in the mloc program (Bergman \& Solomon 1990; Walker et al. 2011; Bergman et al. submitted).

The HD algorithm divides the relocation procedure into two distinct inverse problems that each utilize customized phase arrival time data (e.g. Karasözen et al. 2016, 2018). The first step uses arrival times of all phases recorded at all distances to determine 'cluster vectors' that relate the locations and origin times of each individual event with respect to the geometrical mean of all events, the 'hypocentroid'. The second step uses direct $P g$ and $S g$ phases at epicentral distances $<2^{\circ}$ - at which biases from unknown velocity structure are minimal - to establish the absolute location and origin time of the hypocentroid. The cluster vectors, added to the absolute hypocentroid, yield the 'calibrated' coordinates of all events: latitude, longitude, focal depth, origin time, and their uncertainties. The HD method can solve for focal depth as a free parameter if all events in the cluster have near-distance readings; around one third of the nearly 700 relocated earthquakes were determined in this way. For most of the remainder, we set the depths manually by minimizing the residuals at close-in stations. For around 100 events, focal depths were fixed to a default value of $10 \mathrm{~km}$ for the Çameli cluster and $15 \mathrm{~km}$ for the other clusters.

By analyzing fits to $P g$ and $P n$ at the closest stations and $P n$ and $S n$ at regional distances, we settled upon a two-layered crustal velocity model with $V_{P} 5.7 \mathrm{~km} / \mathrm{s}$ and $V_{S} 3.25 \mathrm{~km} / \mathrm{s}$ for the upper 
$20 \mathrm{~km}$ and $V_{P} 6.2 \mathrm{~km} / \mathrm{s}$ and $V_{S} 3.6 \mathrm{~km} / \mathrm{s}$ from $20 \mathrm{~km}$ to the Moho at $40 \mathrm{~km}$. Below the Moho, we used velocities from the $a k 135$ 1-D Earth model (Kennett et al. 1995). The relocation procedure eliminates systematic biases of up to $\sim 0.5 \mathrm{sec}$ and $\sim 1.5 \mathrm{sec}$ in $P g$ and $S g$ residual travel times, respectively, and reduces their root mean square errors from starting values of $\sim 1-2$ sec down to 0.3-0.6 sec. We have posted detailed information on each cluster - such as arrival time compilations, station coordinates and calibration raypaths, velocity models, travel time residual plots, focal depth histograms, and epicentral uncertainties — to the Global Catalog of Calibrated Earthquake Locations database (Bergman et al. (submitted); see Data Availability).

Resulting, calibrated hypocenters have typical uncertainties of $\sim 1-2 \mathrm{~km}$ in latitude and longitude. Focal depth accuracy depends strongly on the availability of close-in stations, meaning those at epicentral distances less than $\sim 1-2$ times the focal depth (e.g. Gomberg et al. 1990). In two previous studies of ours in neighbouring regions of western Turkey, we estimated these uncertainties at $\sim 2 \mathrm{~km}$ where close-in stations are available and $\sim 5 \mathrm{~km}$ where they are not (Karasözen et al. 2016, 2018). This marks a significant improvement on the relocated ISC-EHB catalogue, whose focal depth uncertainties have been estimated at $\sim 10-15 \mathrm{~km}$ (Engdahl et al. 2006). However, a comparison between our calibrated focal depths and centroid depths from regional waveform modelling reveals the former to be on average several kilometers deeper, with respective means of $\sim 8 \mathrm{~km}$ and $\sim 14 \mathrm{~km}$ (Supplementary Figure S1). This discrepancy holds for individual seismic sequences and is consistent across three orders of magnitude $\left(M_{w} 3-6\right)$. It also mimics patterns observed elsewhere in western Turkey (Karasözen et al. 2016, 2018; Mutlu 2020) and in similarly well-instrumented regions of Alaska (Gaudreau et al. 2019) and Israel (Haddad et al. 2020). Our interpretation is that for most of the events analyzed, calibrated relocations provide an upper bound on focal depth while regional waveform modelling is better at resolving the shallowest earthquake depths. 


\subsection{Regional compilation of well-located earthquake focal mechanisms}

Lastly, we compiled a regional catalogue of well-located earthquake focal mechanisms by combining our own results with source parameters from the literature. We found a total of 299 earthquake focal mechanisms across the region shown in Figures 2 and 3; the full catalogue, with references, is given in Supplementary Table S3. Of the larger events (greater than $M_{w} \sim 5$ ) between 1955 and 2019, fifteen mechanisms were estimated using first motion polarities, thirty-six using teleseismic long-period body waveform modelling, and sixty-five were determined by the Global Centroid Moment Tensor (GCMT) project. In addition, 183 smaller events $\left(M_{w} 3-5\right)$ were calculated using regional waveform modelling or first motions (mostly the former), but these go back only as far as 2001, around the time that station coverage across Turkey started to improve markedly. Of the 299 focal mechanism events, 241 have hypocenters determined from calibrated relocations, either

in this study or by Karasözen et al. (2016, 2018). Most of the remainder are offshore earthquakes characterized by large azimuthal gaps at regional distances, making their precise relocation difficult. For these earthquakes, we choose the best available hypocenter from the ISC where possible: in most cases, we took the parameters listed in the relocated ISC-EHB catalogue (Engdahl et al. 1998; Weston et al. 2018).

\section{THE RECENT ACıPAYAM, BOZKURT AND ARICıLAR EARTHQUAKE SEQUENCES}

\subsection{The 20 March 2019 $M_{w}$ 5.6 Acıpayam earthquake}

This earthquake struck the Acıpayam basin on 20 March 2019 at 06:34 UTC and 09:34 local time (Figure 4). According to the Kandilli Observatory and Earthquake Research Institute (KOERI), Modified Mercalli intensities reached VI in the eastern basin, where several rural homes were completely destroyed, and V in the town of Acıpayam in the western basin, where three people were injured by falling debris. The United States Geological Survey (USGS) "Did You Feel It?" service documents felt reports as far away as İzmir, $\sim 240 \mathrm{~km}$ west of the epicenter. 


\section{E. Nissen et al.}

InSAR data reveal a NW-SE-oriented elliptical fringe pattern with line-of-sight displacements of up to $\sim 5 \mathrm{~cm}$ away from the satellite (Figure 5a, left column). Since the pattern is similar in ascending and descending interferograms, these displacements must be dominated by vertical rather than horizontal motions. Our elastic dislocation modelling best reproduced the observed ground deformation with normal slip on a buried, moderately $\left(54^{\circ}\right)$ NE-dipping model fault that projects to the surface within the flat, central Acipayam basin (Figure 5a, center and right columns; Figure 6a; and Table 1). Our relocated hypocenter lies just down-dip of the southeastern extent of model slip patch, suggesting that the mainshock rupture propagated upwards and unilaterally towards the NW (Figure 6a). An alternative, SW-dipping model fault reproduced the data nearly as well, but we consider this geometry unlikely on the basis that the relocated hypocenter would be located updip of the main slip area (Supplementary Figure S1). On our preferred, NE-dipping model fault, slip is restricted to a depth range of $\sim 4-9 \mathrm{~km}$ with peak slip of $\sim 0.3 \mathrm{~m}$ at $\sim 6 \mathrm{~km}$ depth (Figure 6b), matching the minimum misfit centroid depth from teleseismic body waveform modelling (Figure 7a) and only slightly shallower than the $\sim 7 \mathrm{~km}$ centroid depth estimated using regional waveforms. The InSAR model moment lies in the middle of the range of seismological estimates, suggesting negligible contribution to modelled slip from early aftershocks or afterslip. Finally, we note that our preferred source parameters are in good agreement with alternative InSAR-derived slip models by Yang et al. (2020) and Elliott et al. (2020), with discrepancies of $10^{\circ}$ or less in strike, dip and rake, and near-identical slip depth ranges.

The mainshock was preceded $\sim 5$ hours earlier by a moderate $\left(M_{w} 3.7\right)$ foreshock, located $\sim 1 \mathrm{~km}$ to the SE and with a similar normal mechanism (Figure 6a and Supplementary Table S2). An abundant aftershock sequence includes 193 earthquakes with sufficient station picks for precise relocation, of which twenty-three were sufficiently large $\left(M_{w} 3.5-5.1\right)$ that we could obtain robust focal mechanisms and centroid depths. The aftershocks form a diffuse distribution, with several colocated with the mainshock slip region but others lying well away from it. Centroid depths range from 3-15 km, with the greatest concentration at $4-5 \mathrm{~km}$, but likely uncertainties of up to a few kilometers make it difficult to ascertain whether the colocated events lie on, or off (below or 
above), the mainshock fault plane. Southern aftershocks — including a cluster around the southern end of the mainshock slip region — tend to have normal mechanisms similarly oriented to that of the mainshock and so might plausibly lie on the same fault plane. Northern aftershocks, on the other hand, involve normal faulting with a greater diversity of orientations including a few orthogonal to the main fault plane. The northern aftershocks also include a few oblique slip events and a single strike-slip earthquake.

The mainshock fault is highly oblique to the sinistral-normal Acspayam fault in the southern Acıpayam basin (Kürçer et al. 2016; Emre et al. 2018) and somewhat oblique to a number of unnamed, N-S-trending normal faults portrayed across the eastern basin by Alçiçek et al. (2006) and Elitez \& Yaltırak (2016) (Figure 6a). However, the mainshock fault itself was not recognized prior to the 2019 earthquake and there are no clear fault scarps visible along its surface projection, even with the aid of high-resolution topographic imagery (Elliott et al. 2020). This suggests either that shallow extension is accommodated elsewhere — perhaps by distributed deformation — or that the fault is structurally immature, by which we mean that it has yet to accommodate appreciable cumulative slip. The inference of structural immaturity is consistent with our observation of diffuse aftershock seismicity, much of it presumably on structures subsidiary to the mainshock fault (Powers \& Jordan 2010; Pousse-Beltran et al. 2020; Perrin et al. 2021). Some of the N-S-oriented aftershocks, including the largest $\left(M_{w}\right.$ 5.1) on 31 March 2019, may have occurred on the faults mapped by Alçiçek et al. (2006) and Elitez \& Yaltırak (2016). However, none of the aftershocks are colocated with the larger Acıpayam fault and so we cannot provide new information on its kinematics.

\subsection{The 8 August $2019 M_{w} 5.8$ Bozkurt earthquake}

This earthquake struck near the town of Bozkurt in the western Acıgöl basin on 8 August 2019 at 11:25 UTC and 14:25 local time (Figure 4). Peak intensities of VI were recorded in and around the town of Bozkurt (KOERI) and $\sim 23$ people were injured and more than 100 houses heavily damaged. The earthquake was felt at İzmir, $\sim 230 \mathrm{~km}$ to the West, and Konya, $\sim 250 \mathrm{~km}$ to the 


\section{E. Nissen et al.}

East (USGS).

Radar interferograms exhibit a circular fringe pattern centered on Maymundağ mountain, north of Acigöl basin (Figure 5b, left column). The pattern is clearest in the descending interferogram, where peak line-of-sight displacements are $\sim 4 \mathrm{~cm}$ away from the satellite. We replicated the observed deformation most closely with normal slip on a buried, $\sim \mathrm{N}$ - or $\sim \mathrm{S}$-dipping model fault, though we found fault strike to be poorly resolved due to the circular deformation pattern. We favour the N-dipping model since its parameters are in much closer agreement with our teleseismic body waveform focal mechanism than those of the S-dipping model fault (Figure 6c, center and right columns; Figure 7b; Table 1). Our relocated hypocenter lies at the western edge of the modelled fault slip, suggesting unilateral, eastward rupture. Model fault slip occurs at depths of $\sim 6-10 \mathrm{~km}$ with peak slip of $\sim 0.6 \mathrm{~m}$ at $\sim 8.5 \mathrm{~km}$ (Figure $6 \mathrm{~d}$ ). Our teleseismic waveform model centroid depth is somewhat deeper at $\sim 12 \mathrm{~km}$, though we find similar waveform misfits across the centroid depth range 9-14 km. Our minimum misfit centroid depth from regional waveform modelling lies near the shallow end of this range, at $\sim 10 \mathrm{~km}$. The InSAR model moment and moment magnitude $\left(M_{w} 6.0\right)$ are larger than any of the available seismological solutions, hinting that the modelled fault slip incorporates some postseismic afterslip.

A $M_{w} 4.1$ foreshock and six $M_{w} 3.6-4.0$ aftershocks were sufficiently well-recorded for regional waveform modelling, and seven smaller aftershocks could also be precisely relocated (Figure 6c). The larger events involved predominantly normal faulting mechanisms - mostly oriented $\sim \mathrm{E}-\mathrm{W}$ except for one which was oriented $\sim \mathrm{N}-\mathrm{S}-$ at centroid depths of 5-11 km. Several of the aftershocks are located close to the up-dip edge of the InSAR-derived model slip distribution, though the limited depth resolution precludes any firm association or interpretation.

The surface projection of our model fault aligns closely with a mapped, N-facing scarp in the southern part of Acıgöl basin, $\sim 3 \mathrm{~km}$ north of the main, rangefront-forming Acıgöl fault (Figure 5b). Topographic profiling indicates that the scarp is around 5-10 $\mathrm{m}$ high. Its involvement in 
the August 2019 sequence may indicate a basinward migration or reorganization of the Acigöl fault zone that helps straighten a curved embayment in the southern basin margin. However, only the deep portion of this fault ruptured in the 2019 Bozkurt earthquake. We tentatively suggest that the S-dipping Maymundağ fault — which bounds the northern margin of the basin and which presumably abuts the N-dipping fault at depths of several kilometers - may have formed a structural barrier across which slip in the Bozkurt earthquake failed to propagate. This is similar to inferences made on the depth extents of certain reverse faulting earthquakes (Elliott et al. 2011, 2013; Savidge et al. 2019).

\subsection{The 24 November $2017 M_{w} 5.3$ Arıcılar earthquake}

This event struck the mountainous region east of Muğla in the southwestern part of the study area (Figure 8), very close to the small hamlet of Arıcilar after which we have named it. A $M_{w} 5.1$ foreshock struck at 20:22 UTC (23:22 local time) on 22 November 2017 and is associated with peak intensities of V (KOERI). The $M_{w} 5.3$ mainshock occurred at 21:49 UTC on 24 November 2017 (at 00:49 on 25 November 2017, local time) and was felt at both Muğla and Fethiye (USGS). To our best knowledge, neither earthquake caused significant damage or injury.

All of the available InSAR imagery captures both the foreshock and mainshock. Ascending and descending coseismic interferograms each exhibit an E-W-oriented, elliptical fringe pattern with peak line-of-sight displacements of $\sim 11-14 \mathrm{~cm}$ (Figure 9, left column). Observed displacements were best reproduced by normal slip on a S-dipping model fault that extends from the surface to $\sim 4 \mathrm{~km}$ depth (Figure 9, center and right columns; Figure 10; Table 1). The foreshock and mainshock are both colocated with the model slip area and their combined seismological moments approximate the InSAR model moment, suggesting that both events contributed to the observed surface deformation. Model slip peaks at $\sim 30-40 \mathrm{~cm}$ at $\sim 2 \mathrm{~km}$ depth, and few centimeters of model slip reaches the surface over a distance of $4 \mathrm{~km}$, suggesting that a small surface rupture may have occurred (Figure 10b). Very shallow coseismic slip is further supported by our regional moment tensor centroid depths of $\sim 1-2 \mathrm{~km}$, which additional depth resolution tests (Section 2.3) 
confirmed as being robust. Such shallow rupture is unusual in continental crust of the eastern Mediterranean and Middle East, but we note that it is not unprecedented (Savidge et al. 2019; Elias et al. 2021).

The causative fault is not evident in the topography and was not known prior to the earthquake. However, it is only a few kilometers along strike from — and only $\sim 20^{\circ}$ oblique to — the easternmost mapped extent of the SSW-dipping Muğla normal fault, which has a similar geological slip vector to that of our InSAR model (Howell et al. 2017). We therefore consider that the 2017 earthquakes ruptured an eastern continuation of the Muğla fault zone.

\section{DISCUSSION}

Next, we discuss the broader patterns of seismicity along the Fethiye-Burdur trend revealed by our new compilation of focal mechanisms and relocated epicenters. Where possible, we compare focal mechanisms with geological or geomorphic indicators of fault kinematics, and we also test their consistency against the GPS-based tectonic models shown in Figure 2. Our analysis starts in the northern study area where we also add a detailed reassessment of the 12 May $1971 M_{w} 6.0$ Burdur earthquake, one of the largest and most destructive instrumental events in western Turkey. Our focus then switches to the southern study area, between Fethiye and Çameli. The section concludes with a brief discussion of the forces likely to be driving the observed deformation.

\subsection{Seismicity along the northern Fethiye-Burdur trend}

Within the northern study area, earthquake focal mechanisms indicate a predominance of shallow normal faulting with a wide diversity of orientations (Figure 4). There are only a very few scattered strike-slip events - all with small to moderate magnitudes — and there is certainly no evidence for a through-going strike-slip fault zone as depicted in early GPS models (e.g. Figure 2c). Nodal plane orientations are instead broadly consistent with the smoothed GPS strain rate field of Howell et al. (2017), shown in Figure 2d. In particular, the area between the Acıpayam basin in the SW and the Akşehir-Afyon graben in the NE — known colloquially as Turkey's 'Lake District' — 
contains a mix of NW-, W- and SW-trending normal mechanisms (Figure 3), in good agreement with radially-divergent strain inferred by Howell et al. (2017). Indeed, we consider it likely that the orthogonal normal faulting is partly responsible for the numerous lacustrine basins across this region.

Regarding the purported FBFZ, several earthquakes with well-constrained focal mechanisms are colocated with NE-trending faults and therefore warrant closer scrutiny (Figure 4); the largest of these, the 12 May $1971 M_{w} 6.0$ Burdur earthquake, is assessed in a separate subsection below. Elsewhere, two earthquakes with relocated hypocenters within the Tefenni basin are of particular interest, since several NE-striking sinistral strike-slip faults have been mapped close by and reported as active (Aksoy \& Aksarı 2016). The larger of the relocated earthquakes - a $M_{w} 5.5$ earthquake on 30 January 1964 near Karamanlı — has a first motions mechanism consistent with steep, SW-dipping sinistral-normal faulting (Canitez \& Üçer 1967) and may have ruptured one of a number of NW-striking faults mapped in this area. The smaller earthquake $-\mathrm{a} M_{w} 3.6$ event on 21 July 2019 - is colocated with a NE-trending fault, but our regional waveform model indicates predominantly normal motion. Likewise, a $M_{w} 4.6$ earthquake on 4 Dec 2009 with a normal mechanism (Över et al. 2013) is colocated with the northern end of the NE-trending Çameli fault, listed by Emre et al. (2018) as a sinistral strike-slip fault. This lends support to the competing interpretation of Alçiçek et al. (2006) and Özkaptan et al. (2018) that the Çameli fault accommodates normal slip, and is also consistent with a recent paleoseismic study that showed predominantly normal motion on the nearby, parallel Acıpayam fault (Kürçer et al. 2016).

A $m_{b} 5.3$ earthquake on 9 September 1971, relocated to the Korkuteli basin in the SE of Figure 4, was previously assigned a pure strike-slip mechanism from teleseismic $P$ waveform modelling (Y1lmaztürk \& Burton 1999). However, only ten waveforms were used in this study and the authors recognize that there are large residuals at some stations leading to large uncertainties in the mechanism. Moreover, Y1lmaztürk \& Burton's centroid depth of $34 \mathrm{~km}$ is inconsistent with our focal depth of $15 \mathrm{~km}$ and with other regional focal depths. This earthquake has been used elsewhere 
to argue for a left-lateral FBFZ (Hall et al. 2009), but we consider its published source parameters to be questionable and do not include it in our focal mechanism database. Further south and east, the Bey Dağları mountains and Aksu basin are characterized by mostly N-S-trending normal faulting mechanisms (Figure 3), consistent with regional E-W extensional strain (Figure 2d). This style of faulting also seems to predominate further east still, in the western Taurus mountains.

\subsection{The 12 May $1971 M_{w}$ 6.0 Burdur earthquake revisited}

The destructive 12 May $1971 M_{w} 6.0$ Burdur earthquake caused extensive damage to villages at the southern end of Lake Burdur and killed 57 people (Figure 4). Teleseismic waveform modelling of the mainshock resolved two distinct sub-events separated by 9 seconds, each exhibiting a predominantly normal mechanism with moderate dip angle $\left(35-56^{\circ}\right) \mathrm{SW}$ - and NE-striking nodal planes and a centroid depth of $12 \mathrm{~km}$ (Taymaz \& Price 1992). Two early aftershocks also have predominantly normal mechanisms, but with steeper $\left(65^{\circ}\right.$ or $\left.90^{\circ}\right) \mathrm{NW}$-dipping nodal planes consistent with normal faulting downthrown on the NW side (McKenzie 1978; Taymaz \& Price 1992). Documentation of primary surface rupturing is inconclusive, but cracks were observed along the SE margin of the lake, downthrown $20-30 \mathrm{~cm}$ to the NW. Collectively, these observations implied to Taymaz \& Price (1992) that the NW-dipping Hacilar and Suludere faults - which form the clear topographic scarp along the SE margin of Burdur basin — were responsible for the 1971 earthquake, with the possible additional involvement of the Pınarbaşı fault in the northern Tefenni basin.

Our hypocentral relocations place the Burdur mainshock and largest two aftershocks close to Lake Salda, $30 \mathrm{~km}$ WSW of Lake Burdur (Figure 4). Smaller relocated aftershocks form a broader distribution between Lake Salda in the WSW and the southern end of Lake Burdur in the ENE. The orientation of the aftershock cloud matches the strike of the mainshock nodal planes but its length of 30-40 km likely exceeds that of the $M_{w} 6.0$ mainshock fault plane based on scaling relations (Wells \& Coppersmith 1994). The easternmost aftershocks are therefore likely to be situated some distance along strike from the mainshock rupture. Collectively, this suggests that the Burdur mainshock propagated unilaterally towards the ENE from its epicenter near Lake Salda, but that it 
terminated well short of the Hacilar and Suludere faults that were attributed to this earthquake by Taymaz \& Price (1992). The heavy damage to villages at the southern end of Lake Burdur likely reflects this rupture directivity, while the cracks observed along the SE margin of the lake might reflect secondary deformation related to liquefaction or landsliding which were also observed in this area.

The Burdur mainshock faulting is therefore confined to the area between Salda and Yarışlı Lakes, which exhibits indistinct surface geomorphology and lacks mapped surface faulting. The tight clustering of the mainshock and two largest aftershocks coupled with their diversity of nodal plane dip angles suggests high structural complexity within the source region. These observations hint that the $M_{w} 6.0$ Burdur earthquake ruptured an immature fault with low cumulative slip, much like the $2019 M_{w} 5.7$ Acipayam and $M_{w} 5.9$ Bozkurt earthquakes analyzed in Section 3.1-3.2. Focal mechanisms of the Burdur sequence, dominated by NE-SW-trending normal faulting mechanisms, are also consistent with our inference of radial extension within the northern Fethiye-Burdur trend in Section 4.1.

\subsection{Seismicity along the southern Fethiye-Burdur trend}

In the southern part of the study area, the fifteen moderate magnitude earthquakes (up to $M_{w} 5.4$ ) with assigned focal mechanisms almost exclusively involve ESE-WNW-oriented normal faulting and there is no evidence of any strike-slip activity (Figure 8). None of the earthquakes can be linked to any mapped structures, although the 2017 Arıcilar earthquake occurred only a few kilometers along strike from the eastern end of the Muğla fault zone (Figure 10). Instead, most of the earthquakes, exemplified by the Arıcılar event, appear to lack any clear topographic expression and can be inferred to have ruptured structurally-immature faults. The more prominent, mapped faults in the area mostly follow northeasterly trends (Alçiçek et al. 2006; Alçiçek 2007), but the few relocated earthquakes along these structures are too small for robust focal mechanisms and so we cannot offer further insight into their kinematics . 
The earthquake focal mechanisms are in very good agreement with the GPS strain rate field of Howell et al. (2017) which indicates NNE-SSW oriented extension in this area. This calls into question the relative activity of the NE-trending faults, which are much clearer in the geomorphology, exhibit abundant normal sense slickensides on exposed fault planes (Alçiçek et al. 2006; Howell et al. 2017; Özkaptan et al. 2018; Tosun et al. 2021), but appear poorly oriented with respect to the modern strain rate field for continued extension. The most prominent cluster of ESE-WNW-oriented normal faulting earthquakes, southwest of Çameli, even appears to cross-cut nearby NE-trending faults bounding the southern Çameli basin (Figure 8). We next consider two possible ways to reconcile these observations.

Firstly, counterclockwise vertical axis rotations may have acted to reorient the older faults, which are of Late Miocene age (Alçiçek et al. 2006), into their current, kinematically-unfavourable positions. However, current counterclockwise rotation rates in this region are only $\sim 2-3^{\circ} / \mathrm{Myr}$ (Howell et al. (2017); Figure 2d) and paleomagnetic data indicate cumulative counterclockwise rotations of $\sim 11-15^{\circ}$ since the Late Miocene (Kaymakc1 et al. 2018). This is clearly insufficient to account fully for the roughly $\sim 60^{\circ}$ difference in strike between the instrumental earthquake nodal planes and the largest faults. A second possibility is that there has been a recent change in the regional strain field, from NW-SE-directed extension to NNE-SSW extension. Fault kinematic and tectonostratigraphic data from the Çameli basin support such a change and constrain its timing to the late Quaternary (Alçiçek et al. 2006). We speculate that the switch might be related to eastward propagation of the Gökava graben into the area (Tur et al. 2015) and/or to lateral gradients in gravitational potential energy introduced by rapid subsidence of the Rhodes basin (Hall et al. 2009) (Figure 3).

\subsection{Dynamics of the deformation}

Data from multiple sources indicate radial horizontal extension at the northern end of the FethiyeBurdur trend. We now discuss why this radial extension might occur. Processes that are thought to drive deformation in the Aegean and Anatolia include: (1) slab rollback in the Hellenic and 
Cyprus subduction zones, possibly associated with one or more tears in the down-going Nubian plate; (2) the Nubia-Arabia-Eurasia collision; and (3) contrasts in gravitational potential energy (GPE) between the eastern Mediterranean sea floor and the continental lithosphere of Greece and Turkey. Of this, it is unclear how much (if at all) subduction rollback or the Arabian-Eurasia collision influence observed present-day strains in SW Turkey, or whether a possible tear in the Nubian plate beneath the Fethiye-Burdur trend contributes to surface deformation. By contrast, it is almost certain that contrasts in GPE contribute significantly to surface deformation in SW Turkey, given the $\sim 4-6 \mathrm{~km}$ differences in elevation between the deep Rhodes and Antalya basins and the Bey Dağları mountains between Fethiye and Antalya. We now consider deformation in SW Turkey in the light of previously published models of GPE contrasts.

Özeren \& Holt (2010) calculated the deviatoric stress field expected from GPE contrasts alone (without applying any compressional boundary condition). The regime in their model aligns very well with our smoothed strain-rate field in Figure $2 \mathrm{~d}$ - although we note that the modelled stress field exhibits a strong dependence on modelled crustal thickness. Their model predicts a localized area of radial extensional stresses around Burdur, apparently caused by the superposed effects of two lateral gradients in GPE: (1) a NE-SW gradient between Burdur and the Rhodes Basin; and (2) a NW-SE gradient between Burdur and the Antalya basin. Both west and east of Burdur, the stress field predicts more uniaxial horizontal extension associated with each GPE gradient; radial horizontal extension is only expected in the region equidistant from the Rhodes and Antalya basins. Lateral variations in GPE are therefore sufficient to explain the large-scale pattern of surface deformation in SW Turkey, although it is hard to rule out contributions from other dynamic processes.

\section{CONCLUSIONS}

Our refined and updated earthquake catalog for southwestern Turkey reveals no evidence for NEtrending, active strike-slip faults along the Fethiye-Burdur trend, as has previously been posited. Instead, the western limb of the Isparta Angle is characterized by shallow normal faulting earth- 
quakes, with a diversity of orientations in the north (across Turkey's Lake District), mostly N-S nodal planes in the east (in the Bey Dağları mountains), and ESE-WNW nodal planes in the south (near Fethiye and Çameli). In each case, fault orientations are consistent with the principal axes of the horizontal strain rate tensor calculated from regional GPS velocities (Howell et al. 2017). These kinematics appear to be driven principally by lateral gradients in gravitational potential energy between the high Anatolian plateau and the deep Rhodes and Antalya basins.

Three earthquake sequences associated with clear InSAR signals provide additional information on how active faulting is manifest in the topography. The $2019 M_{w} 5.6$ Acıpayam earthquake involved buried slip on a previously unrecognized fault with no discernible geomorphic expression. The $2019 M_{w} 5.8$ Bozkurt earthquake was also buried, but its fault plane aligns with subtle (510 m-high) surface scarps that had previously been mapped. The $2017 M_{w} 5.3$ Arıcilar earthquake slipped at shallower depths but also failed to break to the surface; its causative fault lies a few kilometers along strike of the mapped Muğla fault zone but also appears indistinct in the topography. All three of these earthquakes can therefore be inferred to have ruptured structurally-immature (low cumulative slip) faults. Our relocation of the destructive 1971 Burdur sequence hints that this also ruptured a structurally-immature fault zone with an indistinct expression in the topography. These observations raise the spectre that across southwestern Turkey damaging earthquakes (of up to at least $M_{w} 6$ ) are possible on faults that would prove difficult to identify beforehand.

\section{ACKNOWLEDGMENTS}

E. N. was supported by a Canada Research Chair and grants from the Natural Sciences and Engineering Research Council of Canada (NSERC Discovery Grant 2017-04029), the Canada Foundation for Innovation, and the BC Knowledge Development Fund. E. G. was funded through an Alexander Graham Bell Canada Graduate Scholarship from NSERC, and a Montalbano Scholars Fellowship and President's Research Scholarship, both from University of Victoria. E. S. was supported by an Undergraduate Student Research Award from NSERC and a Jamie Cassels Undergraduate Research Award from the University of Victoria. 


\section{Data Availability}

Interferograms were constructed using Copernicus Sentinel-1 data (2017, 2019) available from https://scihub.copernicus.eu/. Corresponding interferograms are also available to download from the COMET LiCS database (Wright et al. 2016), which we exploited during our initial reconnaissance of the Acıpayam, Bozkurt and Arıcilar earthquakes. Teleseismic waveforms were accessed through IRIS Data Services, and specifically the IRIS Data Management Center (https://ds.iris.edu/ds/nodes/dmc/) which are funded through the Seismological Facilities for the Advancement of Geoscience and EarthScope (SAGE) Proposal of the National Science Foundation under Cooperative Agreement EAR-1261681. Regional waveforms were obtained from the Aristotle University Of Thessaloniki Seismological Network (1981) (https://doi.org/10.7914/SN/HT), the Disaster And Emergency Management Authority (1990) of Turkey (https://doi.org/10.7914/SN/TU), the Technological Educational Institute Of Crete (2006) (https://doi.org/10.7914/SN/HC), the Kandilli Observatory and Earthquake Research Institute, Boğaziçi University (1971) (https://doi.org/10.7914/SN/KO), and the National Observatory Of Athens, Institute Of Geodynamics (1997) (https://doi.org/10.7914/SN/HL). Arrival times were gathered from the Disaster And Emergency Management Authority (1990) of Turkey, the Kandilli Observatory and Earthquake Research Institute, Boğaziçi University (1971), the National Observatory Of Athens, Institute Of Geodynamics (1997), and the International Seismological Centre (ISC) Bulletin (https://doi.org/10.31905/D808B830).

Our full, calibrated relocation results are available through the Global Catalog of Calibrated Earthquake Locations (GCCEL) database (https://www.sciencebase.gov/catalog/item/59fb91fde4b0531197b16ac7) (Bergman et al. submitted). Additional location parameters were taken from the ISC's relocated ISC-EHB dataset (https://doi.org/10.31905/PY08W6S3) and their ISC-GEM Earthquake Catalogue (https://doi.org/10.31905/d808b825). We used focal mechanisms from the Global Centroid Moment Tensor project (https://www.globalcmt.org/); from the U.S. Geological Survey's Comprehensive Earthquake Catalog (https://earthquake.usgs.gov/data/comcat/); and from the GEOFON Data Centre (1993) of the GFZ German Research Centre for Geosciences (https://geofon.gfZpotsdam.de/) which are based on data from the GEOFON Extended Virtual Network (GEVN) 
partner networks. Complete references for these earthquake parametric data sources are given in Supplementary Table 2 .

The ISOLA software can be downloaded from http://seismo.geology.upatras.gr/isola/ and Mloc source code from https://www.sciencebase.gov/catalog/item/ 59fb91fde4b0531197b16ac7. Other codes used in the paper will be shared upon reasonable request to the corresponding author. All figures in this paper were plotted using Generic Mapping Tools (Wessel et al. 2013).

\section{REFERENCES}

Aksarı, D., Karabulut, H., \& Özalaybey, S., 2010. Stress interactions of three moderate size earthquakes in Afyon, southwestern Turkey, Tectonophys., 485(1), 141-153.

Aksoy, R. \& Aksarı, S., 2016. Neogene-Quaternary evolution of the Tefenni basin on the Fethiye-Burdur fault zone, SW Anatolia-Turkey, J. Asian Earth Sci., 118, 137-148.

Aktug, B., Nocquet, J. M., Cingöz, A., Parsons, B., Erkan, Y., England, P., Lenk, O., Gürdal, M. A., Kilicoglu, A., Akdeniz, H., \& Tekgül, A., 2009. Deformation of western Turkey from a combination of permanent and campaign GPS data: Limits to block-like behavior, J. Geophys. Res., 114.

Alçiçek, M. C., 2007. Tectonic development of an orogen-top rift recorded by its terrestrial sedimentation pattern: The Neogene Eșen Basin of southwestern Anatolia, Turkey, Sed. Geol., 200(1-2), 117-140.

Alçiçek, M. C., 2015. Comment on "The Fethiye-Burdur Fault Zone: A component of upper plate extension of the subduction transform edge propagator fault linking Hellenic and Cyprus Arcs, Eastern Mediterranean. Tectonophysics 635, 8099” by J. Hall, A.E. Aksu, İ. Elitez, C. Yaltırak, G. Çifçi, Tectonophys., 664, 1-4.

Alçiçek, M. C., Ten Veen, J. H., \& Özkul, M., 2006. Neotectonic development of the Cameli Basin, southwestern Anatolia, Turkey, Geol. Soc. London Spec. Publ., 260(1), 591-611.

Alçiçek, M. C., Brogi, A., Capezzuoli, E., Liotta, D., \& Meccheri, M., 2013. Superimposed basin formation during Neogene-Quaternary extensional tectonics in SW-Anatolia (Turkey): Insights from the kinematics of the Dinar Fault Zone, Tectonophys., 608, 713-727.

Aristotle University Of Thessaloniki Seismological Network, 1981. Permanent Regional Seismological Network operated by the Aristotle University of Thessaloniki.

Barka, A. \& Reilinger, R., 1997. Active tectonics of the Eastern Mediterranean region: deduced from GPS, neotectonic and seismicity data, Annali di Geofisica, 40(3), 587-610.

Benetatos, C., Kiratzi, A., Papazachos, C., \& Karakaisis, G., 2004. Focal mechanisms of shallow and intermediate depth earthquakes along the Hellenic Arc, J. Geodynamics, 37, 253-296. 
Bergman, E. A. \& Solomon, S. C., 1990. Earthquake swarms on the Mid-Atlantic Ridge — Products of magmatism or extensional tectonics?, J. Geophys. Res., 95, 4943-4965.

Bergman, E. A., Benz, H, M., Yeck, W. L., Karasözen, E., Engdahl, E. R., Ghods, A., Hayes, G. P., \& Earle, P. S., submitted. A Global Catalog of Calibrated Earthquake Locations, Geophys. J. Int. .

Bouchon, M., 1981. A simple method to calculate Green's functions for elastic layered media, Bull. Seismol. Soc. Am., 71(4), 959-971.

Cambaz, M. D. \& Mutlu, A. K., 2016. Regional moment tensor inversion for earthquakes in Turkey and its surroundings: 2008-2015, Seismol. Res. Lett., 87(5), 1082-1090.

Canitez, N. \& Üçer, S. B., 1967. Computer determinations for the fault-plane solutions in and near Anatolia, Tectonophys., 4(3), 235-244.

Clarke, P. J., Paradissis, D., Briole, P., England, P. C., Parsons, B. E., Billiris, H., Veis, G., \& Ruegg, J.-C., 1997. Geodetic investigation of the 13 May 1995 Kozani-Grevena (Greece) earthquake, Geophys. Res. Lett., 24, 707-710.

Coutant, O., 1989. Program of numerical simulation AXITRA, Tech. rep., Université Joseph Fourier Grenoble, France.

Disaster And Emergency Management Authority, 1990. Turkish National Seismic Network.

Dumont, J. F., Poisson, A., \& Şahinci, A., 1979. Sur l'existence de coulissements sénestres récents a l'extrémité orientale de l'arc égéen (sud-ouest de la Turquie), C. R. Acad. Sci., 289, 261-264.

Elias, P., Spingos, I., Kaviris, G., Karavias, A., Gatsios, T., Sakkas, V., \& Parcharidis, I., 2021. Combined Geodetic and Seismological Study of the December $2020 \mathrm{Mw}=4.6$ Thiva (Central Greece) Shallow Earthquake, Applied Sciences, 11(13), 5947.

Elitez, İ. \& Yaltırak, C., 2016. Miocene to Quaternary tectonostratigraphic evolution of the middle section of the Burdur-Fethiye Shear Zone, south-western Turkey: Implications for the wide inter-plate shear zones, Tectonophys., 690, 336-354.

Elitez, I., Yaltırak, C., Hall, J., Aksu, A. E., \& Çifçi, G., 2015. Reply to the comment by M.C. Alçiçek on "The Fethiye-Burdur Fault Zone: A component of upper plate extension of the subduction transform edge propagator fault linking Hellenic and Cyprus Arcs, Eastern Mediterranean,” Tectonophysics, 635, 80-99, by J. Hall, A.E. Aksu, İ. Elitez, C. Yaltırak and G. Çifçi, Tectonophys., 664, 5-13.

Elitez, İ., Yaltırak, C., \& Aktuğ, B., 2016. Extensional and compressional regime driven left-lateral shear in southwestern Anatolia (eastern Mediterranean): The Burdur-Fethiye Shear Zone, Tectonophys., 688, 26-35.

Elitez, İ., Yaltırak, C., Kürçer, A., Özdemir, E., \& Güldoğan, Ç. U., 2017. A critical review of the Kibyra Fault (Burdur-Fethiye Shear Zone, SW Turkey), Geodinamica Acta, 29(1), 91-102.

Elliott, J. R., Parsons, B., Jackson, J. A., Shan, X., Sloan, R. A., \& Walker, R. T., 2011. Depth segmentation of the seismogenic continental crust: The 2008 and 2009 Qaidam earthquakes, Geophys. Res. Lett., 38. 
Elliott, J. R., Copley, A. C., Holley, R., Scharer, K., \& Parsons, B., 2013. The 2011 Mw 7.1 Van (Eastern Turkey) earthquake, J. Geophys. Res., 118(4), 1619-1637.

Elliott, J. R., de Michele, M., \& Gupta, H. K., 2020. Earth Observation for Crustal Tectonics and Earthquake Hazards, Surveys in Geophysics, 41(6), 1355-1389.

Emre, O., Duman, T. Y., Özalp, S., Şaroğlu, F., Olgun, c., Elmacı, H., \& Çan, T., 2018. Active fault database of Turkey, Bull. Earthquake Eng., 16(8), 3229-3275.

Engdahl, E. R., van der Hilst, R. D., \& Buland, R., 1998. Global teleseismic earthquake relocation from improved travel times and procedures for depth determination, Bull. Seismol. Soc. Am., 88, 722-743.

Engdahl, R. E., Jackson, J. A., Myers, S. C., Bergman, E. A., \& Priestley, K., 2006. Relocation and assessment of seismicity in the Iran region, Geophys. J. Int., 167, 761-778.

England, P., Howell, A., Jackson, J., \& Synolakis, C., 2015. Palaeotsunamis and tsunami hazards in the Eastern Mediterranean, Phil. Trans. R. Soc. Lond. A, 373(2053), 20140374.

England, P., Houseman, G., \& Nocquet, J.-M., 2016. Constraints from GPS measurements on the dynamics of deformation in Anatolia and the Aegean, J. Geophys. Res., 121(12), 8888-8916.

Eyidogan, H. \& Barka, A., 1996. October 1, 1995 Dinar earthquake, western Turkey, Terra Nova, 8, 479-485.

Gaudreau, É., Nissen, E. K., Bergman, E. A., Benz, H. M., Tan, F., \& Karasözen, E., 2019. The August 2018 Kaktovik earthquakes: Active tectonics in northeastern Alaska revealed with InSAR and seismology, Geophys. Res. Lett., 46, 14,412-14,420.

GEOFON Data Centre, 1993. GEOFON Seismic Network.

Glover, C. \& Robertson, A., 1998. Neotectonic intersection of the Aegean and Cyprus tectonic arcs: extensional and strike-slip faulting in the Isparta Angle, SW Turkey, Tectonophys., 298(1), 103-132.

Gomberg, J. S., Shedlock, K. M., \& Roecker, S. W., 1990. The effect of S-wave arrival times on the accuracy of hypocenter estimation, Bull. Seismol. Soc. Am., 80(6A), 1605-1628.

Haddad, A., Alcanie, M., Zahradník, J., Lazar, M., Antunes, V., Gasperini, L., Polonia, A., Mazzini, A., \& Lupi, M., 2020. Tectonics of the Dead Sea Fault Driving the July 2018 Seismic Swarm in the Sea of Galilee (Lake Kinneret), Israel, J. Geophys. Res., 125(10).

Hall, J., Aksu, A. E., Yaltırak, C., \& Winsor, J. D., 2009. Structural architecture of the Rhodes Basin: A deep depocentre that evolved since the Pliocene at the junction of Hellenic and Cyprus Arcs, eastern Mediterranean, Marine. Geol., 258(1-4), 1-23.

Hall, J., Aksu, A. E., Elitez, I., Yaltırak, C., \& Çifçi, G., 2014. The Fethiye-Burdur Fault Zone: A component of upper plate extension of the subduction transform edge propagator fault linking Hellenic and Cyprus Arcs, Eastern Mediterranean, Tectonophys., 635, 80-99.

Herman, M. W., Herrmann, R. B., Benz, H. M., \& Furlong, K. P., 2014. Using regional moment tensors to constrain the kinematics and stress evolution of the 2010-2013 Canterbury earthquake sequence, South 
Island, New Zealand, Tectonophys., 633, 1-15.

Howell, A., Jackson, J., England, P., Higham, T., \& Synolakis, C., 2015. Late Holocene uplift of Rhodes, Greece: evidence for a large tsunamigenic earthquake and the implications for the tectonics of the eastern Hellenic Trench System, Geophys. J. Int., 203(1), 459-474.

Howell, A., Jackson, J., Copley, A., McKenzie, D., \& Nissen, E., 2017. Subduction and vertical coastal motions in the eastern Mediterranean, Geophys. J. Int., 211, 593-620.

Jiménez-Munt, I. \& Sabadini, R., 2002. The block-like behavior of Anatolia envisaged in the modeled and geodetic strain rates, Geophys. Res. Lett., 29(20).

Jónsson, S., Zebker, H., Segall, P., \& Amelung, F., 2002. Fault Slip Distribution of the $1999 M_{w} 7.1$ Hector Mine, California, Earthquake, Estimated from Satellite Radar and GPS Measurements, Bull. Seismol. Soc. Am., 92, 1377-1389.

Jordan, T. H. \& Sverdrup, K. A., 1981. Teleseismic location techniques and their application to earthquake clusters in the South-Central Pacific, Bull. Seismol. Soc. Am., 71, 1105-1130.

Kandilli Observatory and Earthquake Research Institute, Boğaziçi University, 1971. Boğaziçi University Kandilli Observatory and Earthquake Research Institute.

Karasözen, E., Nissen, E., Bergman, E. A., Johnson, K. L., \& Walters, R. J., 2016. Normal faulting in the Simav graben of western Turkey reassessed with calibrated earthquake relocations, J. Geophys. Res., 121, 4553-4574.

Karasözen, E., Nissen, E., Büyükakpınar, P., Cambaz, M. D., Kahraman, M., Ertan, E. K., Abgarmi, B., Bergman, E., Ghods, A., \& Özacar, A. A., 2018. The 2017 July $20 M_{w} 6.6$ Bodrum-Kos earthquake illuminates active faulting in the Gulf of Gökova, SW Turkey, Geophys. J. Int., 214(1), 185-199.

Kaymakc1, N., Langereis, C., Özkaptan, M., Özacar, A. A., Gülyüz, E., Uzel, B., \& Sözbilir, H., 2018. Paleomagnetic evidence for upper plate response to a STEP fault, SW Anatolia, Earth Planet. Sci. Lett., 498, 101-115.

Kennett, B. L. N., Engdahl, E. R., \& Buland, R., 1995. Constraints on seismic velocities in the Earth from traveltimes, Geophys. J. Int., 122, 108-124.

Kikuchi, M. \& Kanamori, H., 1991. Inversion of complex body waves-iii, Bull. Seismol. Soc. Am., 81(6), $2335-2350$.

Kiratzi, A. \& Louvari, E., 2003. Focal mechanisms of shallow earthquakes in the Aegean Sea and the surrounding lands determined by waveform modelling: a new database, J. Geodynamics, 36, 251-274.

Koçyiğit, A., 2005. The Denizli graben-horst system and the eastern limit of western Anatolian continental extension: basin fill, structure, deformational mode, throw amount and episodic evolutionary history, SW Turkey, Geodinamica Acta, 18(3-4), 167-208.

Koçyiğit, A. \& Özacar, A. A., 2003. Extensional neotectonic regime through the NE edge of the outer Isparta Angle, SW Turkey: new field and seismic data, Turk. J. Earth Sci., 12(1), 67-90. 
Kürçer, A., Özdemir, E., Uygun Güldoğan, Ç., \& Duman, T. Y., 2016. The First Paleoseismic Trench Data From Acipayam Fault, Fethiye Burdur Fault Zone, SW Turkey, Bull. Geol. Soc. Greece, 50(1), 75-84.

Maggi, A., Priestley, K., \& Jackson, J., 2002. Focal Depths of Moderate and Large Size Earthquakes in Iran, J. Seismol. Earthquake Eng., 4(2-3), 1-10.

McCaffrey, R. \& Abers, G., 1988. SYN3: A Program for Inversion of Teleseismic Body Wave Forms on Microcomputers, Air force geophysical laboratory technical report, Hanscomb Air Force Base, Massachusetts.

McCaffrey, R., Zwick, P., \& Abers, G., 1991. SYN4 Program, Tech. rep., IASPEI Software Library.

McKenzie, D., 1972. Active Tectonics of the Mediterranean Region, Geophys. J. Int., 30, 109-185.

McKenzie, D., 1978. Active tectonics of the Alpine-Himalayan belt: the Aegean Sea and surrounding regions, Geophys. J. Int., 55(1), 217-254.

Molnar, P. \& Lyon-Caen, H., 1989. Fault plane solutions of earthquakes and active tectonics of the Tibetan Plateau and its margins, Geophys. J. Int., 99, 123-154.

Mutlu, A. K., 2020. Seismicity, focal mechanism, and stress tensor analysis of the Simav region, western Turkey, Open Geosciences, 12, 479-490.

National Observatory Of Athens, Institute Of Geodynamics, 1997. National Observatory of Athens Seismic Network.

Nissen, E., Jackson, J., Jahani, S., \& Tatar, M., 2014. Zagros “phantom earthquakes" reassessed — The interplay of seismicity and deep salt flow in the Simply Folded Belt?, J. Geophys. Res., 119(4), 35613583.

Okada, Y., 1985. Surface deformation due to shear and tensile faults in a half-space, Bull. Seismol. Soc. Am., 75, 1135-1154.

Över, S., Pınar, A., Özden, S., Yılmaz, H., Ünlügenç, U. C., \& Kamacı, Z., 2010. Late cenozoic stress field in the Cameli Basin, SW Turkey, Tectonophys., 492(1), 60-72.

Över, S., Yılmaz, H., Pınar, A., Özden, S., Ünlügenç, U. C., \& Kamacı, Z., 2013. Plio-Quaternary Stress State in the Burdur Basin, SW-Turkey, Tectonophys., 588, 56-68.

Över, S., Özden, S., Kamacı, Z., Yılmaz, H., Ünlügenç, U. C., \& Pınar, A., 2016. Upper crust response to geodynamic processes beneath Isparta Angle, SW Turkey: Revealed by CMT solutions of earthquakes, Tectonophys., 687, 94-104.

Özbakır, A. D., Şengör, A. M. C., Wortel, M. J. R., \& Govers, R., 2013. The Pliny-Strabo trench region: A large shear zone resulting from slab tearing, Earth Planet. Sci. Lett., 375, 188-195.

Özeren, M. S. \& Holt, W. E., 2010. The dynamics of the eastern Mediterranean and eastern Turkey, Geophys. J. Int., 183(3), 1165-1184.

Özkaptan, M., Kaymakci, N., Langereis, C. G., Gülyüz, E., Özacar, A. A., Uzel, B., \& Sözbilir, H., 2018. Age and kinematics of the Burdur Basin: Inferences for the existence of the Fethiye Burdur Fault Zone 
in SW Anatolia (Turkey), Tectonophys., 744, 256-274.

Perrin, C., Waldhauser, F., \& Scholz, C. H., 2021. The Shear Deformation Zone and the Smoothing of Faults With Displacement, J. Geophys. Res., 126(5).

Pousse-Beltran, L., Nissen, E., Bergman, E. A., Cambaz, M. D., Gaudreau, É., Karasözen, E., \& Tan, F., 2020. The $2020 \mathrm{M}_{w} 6.8$ Elazı̆ (Turkey) Earthquake Reveals Rupture Behavior of the East Anatolian Fault, Geophys. Res. Lett., 47(13), e88136.

Powers, P. M. \& Jordan, T. H., 2010. Distribution of seismicity across strike-slip faults in California, J. Geophys. Res., 115(B5).

Press, W. H., Teukolsky, S. A., Vetterling, W. T., \& Flannery, B. P., 1992. Numerical Recipes in C: The Art of Scientific Computing, Cambridge University Press, Cambridge.

Price, S. P. \& Scott, B., 1994. Fault-block rotations at the edge of a zone of continental extension; southwest Turkey, J. Struct. Geol., 16, 381-392.

Reilinger, R., McClusky, S., Vernant, P., Lawrence, S., Ergintav, S., Cakmak, R., Ozener, H., Kadirov, F., Guliev, I., Stepanyan, R., Nadariya, M., Hahubia, G., Mahmoud, S., Sakr, K., ArRajehi, A., Paradissis, D., Al-Aydrus, A., Prilepin, M., Guseva, T., Evren, E., Dmitrotsa, A., Filikov, S. V., Gomez, F., AlGhazzi, R., \& Karam, G., 2006. GPS constraints on continental deformation in the Africa-Arabia-Eurasia continental collision zone and implications for the dynamics of plate interactions, J. Geophys. Res., 111. Savidge, E., Nissen, E., Nemati, M., Karasözen, E., Hollingsworth, J., Talebian, M., Bergman, E., Ghods, A., Ghorashi, M., Kosari, E., Rashidi, A., \& Rashidi, A., 2019. The December 2017 Hojedk (Iran) earthquake triplet-sequential rupture of shallow reverse faults in a strike-slip restraining bend, Geophys. J. Int., 217(2), 909-925.

Shaw, B. \& Jackson, J., 2010. Earthquake mechanisms and active tectonics of the Hellenic subduction zone, Geophys. J. Int., 181, 966-984.

Sokos, E. \& Zahradník, J., 2013. Evaluating Centroid-Moment-Tensor Uncertainty in the New Version of ISOLA Software, Seismol. Res. Lett., 84(4), 656-665.

Sokos, E. N. \& Zahradník, J., 2008. ISOLA a Fortran code and a Matlab GUI to perform multiple-point source inversion of seismic data, Computers \& Geosciences, 34, 967-977.

Taymaz, T. \& Price, S., 1992. The 1971 May 12 Burdur earthquake sequence, SW Turkey: a synthesis of seismological and geological observations, Geophys. J. Int., 108, 589-603.

Taymaz, T., Jackson, J., \& Westaway, R., 1990. Earthquake mechanisms in the Hellenic Trench near Crete, Geophys. J. Int., 102, 695-731.

Taymaz, T., Jackson, J., \& McKenzie, D., 1991. Active tectonics of the north and central Aegean Sea, Geophys. J. Int., 106, 433-490.

Taymaz, T., Wright, T. J., Yolsal, S., Tan, O., Fielding, E., \& Seyitoglu, G., 2007. Source characteristics of the 6 June 2000 Orta Cankiri (central Turkey) earthquake: a synthesis of seismological, geological 
and geodetic (InSAR) observations, and internal deformation of the Anatolian plate, Geol. Soc. London Spec. Publ., 291(1), 259-290.

Technological Educational Institute Of Crete, 2006. Seismological Network of Crete.

Tiryakioğlu, I., Floyd, M., Erdoğan, S., Gülal, E., Ergintav, S., McClusky, S., \& Reilinger, R., 2013. GPS constraints on active deformation in the Isparta Angle region of SW Turkey, Geophys. J. Int., 195(3), $1455-1463$.

Tosun, L., Avşar, U., Avşar, Ö., Dondurur, D., \& Kaymakcı, N., 2021. Active tectonics and kinematics of Fethiye-Göcek Bay, SW Turkey: Insight about the eastern edge of Pliny-Strabo Trenches, J. Struct. Geol., 145.

Tur, H., Yaltırak, C., Elitez, I., \& Sarıkavak, K. T., 2015. Pliocene-Quaternary tectonic evolution of the Gulf of Gökova, southwest Turkey, Tectonophys., 638, 158-176.

Walker, R. T., Bergman, E. A., Szeliga, W., \& Fielding, E. J., 2011. Insights into the 1968-1997 Dashte-Bayaz and Zirkuh earthquake sequences, eastern Iran, from calibrated relocations, InSAR and highresolution satellite imagery, Geophys. J. Int., 187, 1577-1603.

Wells, D. L. \& Coppersmith, K. J., 1994. New Empirical Relationships among Magnitude, Rupture Length, Rupture Width, Rupture Area, and Surface Displacement, Bull. Seismol. Soc. Am., 84(4), 974 1002 .

Wessel, P., Smith, W. H. F., Scharroo, R., Luis, J., \& Wobbe, F., 2013. Generic Mapping Tools: Improved Version Released, Eos Trans. AGU, 94, 409-410.

Weston, J., Engdahl, E. R., Harris, J., Di Giacomo, D., \& Storchak, D. A., 2018. ISC-EHB: reconstruction of a robust earthquake data set, Geophys. J. Int., 214(1), 474-484.

Wimpenny, S. \& Watson, C. S., 2021. gWFM: A Global Catalog of Moderate-Magnitude Earthquakes Studied Using Teleseismic Body Waves, Seismol. Res. Lett., 92(1), 212-226.

Wright, T. J., Parsons, B. E., Jackson, J. A., Haynes, M., Fielding, E. J., England, P. C., \& Clarke, P. J., 1999. Source parameters of the 1 October 1995 Dinar (Turkey) earthquake from SAR interferometry and seismic bodywave modelling, Earth Planet. Sci. Lett., 172, 23-37.

Wright, T. J., Lu, Z., \& Wicks, C., 2003. Source model for the $M_{w} 6.7,23$ October 2002, Nenana Mountain Earthquake (Alaska) from InSAR, Geophys. Res. Lett., 30(18).

Wright, T. J., Gonzalez, P. J., Walters, R. J., Hatton, E. L., Spaans, K., \& Hooper, A. J., 2016. LiCSAR: Tools for automated generation of Sentinel-1 frame interferograms, AGU Fall Meeting Abstr.

Yang, J., Xu, C., Wang, S., \& Wang, X., 2020. Sentinel-1 observation of 2019 M $_{w} 5.7$ Acipayam earthquake: A blind normal-faulting event in the Acipayam basin, southwestern Turkey, J. Geodynamics, 135. Y1lmaztürk, A. \& Burton, P. W., 1999. Earthquake source parameters as inferred from the body waveform modeling, southern Turkey, J. Geodynamics, 27(4), 469-499.

Yolsal-Çevikbilen, S., Taymaz, T., \& Helvacı, C., 2014. Earthquake mechanisms in the Gulfs of Gökova, 
Sığacık, Kuşadası, and the Simav Region (western Turkey): Neotectonics, seismotectonics and geodynamic implications, Tectonophys., 635, 100-124.

Zahradník, J. \& Sokos, E., 2018. ISOLA Code for Multiple-Point Source ModelingReview, in Moment Tensor Solutions, ed. Damico, S., Springer, Cham.

Zahradnik, J., Jansky, J., \& Plicka, V., 2008. Detailed Waveform Inversion for Moment Tensors of $M \sim 4$ Events: Examples from the Corinth Gulf, Greece, Bull. Seismol. Soc. Am., 98(6), 2756-2771.

Zwick, P., McCaffrey, R., \& Abers, G., 1994. MT5 Program, IASPEI Software Library, 4. 
Table 1. Source parameters of the 2017 Arıcilar foreshock and mainshock and the 2019 Acipayam and Bozkurt mainshocks from catalogues (GCMT = Global Centroid Moment Tensor project; USGS = United States Geological Survey ANSS Comprehensive Earthquake Catalog (ComCat); RMT $=$ Regional Moment Tensor solution) and from our own modelling. The listed origin times are those yielded by calibrated earthquake relocations. Location refers to the latitude and longitude of the GCMT and GEOFON centroids, the USGS epicenter, the relocated epicenter for our seismological solutions, and the peak slip patch our InSAR solutions. Depth refers to the centroid depth for all of the seismological solutions, and the depth of peak slip for the InSAR solution.

\begin{tabular}{|c|c|c|c|c|c|c|c|c|}
\hline Event & Source & Location & Strike & Dip & Rake & Depth & Moment (Nm) & $M_{w}$ \\
\hline Arıcilar & GCMT & $37.04^{\circ}, 28.47^{\circ}$ & $130^{\circ}$ & $57^{\circ}$ & $-65^{\circ}$ & $12 \mathrm{~km}$ & $5.48 \times 10^{16}$ & 5.1 \\
\hline $2017-11-22$ & USGS W-phase & $37.051^{\circ}, 28.643^{\circ}$ & $82^{\circ}$ & $32^{\circ}$ & $-130^{\circ}$ & $11.5 \mathrm{~km}$ & $5.04 \times 10^{16}$ & 5.1 \\
\hline \multirow[t]{2}{*}{$20: 22: 52$} & GEOFON & $37.05^{\circ}, 28.64^{\circ}$ & $120^{\circ}$ & $38^{\circ}$ & $-75^{\circ}$ & $10 \mathrm{~km}$ & - & 5.0 \\
\hline & This study (regional waveforms) & $37.1125^{\circ}, 29.5984^{\circ}$ & $91^{\circ}$ & $34^{\circ}$ & $-128^{\circ}$ & $2 \mathrm{~km}$ & $4.00 \times 10^{16}$ & 5.0 \\
\hline Arıcılar & GCMT & $37.03^{\circ}, 28.60^{\circ}$ & $105^{\circ}$ & $49^{\circ}$ & $-82^{\circ}$ & $12 \mathrm{~km}$ & $9.73 \times 10^{16}$ & 5.3 \\
\hline 2017-11-24 & USGS W-phase & $37.085^{\circ}, 28.622^{\circ}$ & $106^{\circ}$ & $43^{\circ}$ & $-85^{\circ}$ & $11.5 \mathrm{~km}$ & $8.24 \times 10^{16}$ & 5.2 \\
\hline \multirow[t]{4}{*}{$21: 49: 15$} & USGS RMT & $37.085^{\circ}, 28.622^{\circ}$ & $110^{\circ}$ & $46^{\circ}$ & $-80^{\circ}$ & $3 \mathrm{~km}$ & $5.61 \times 10^{16}$ & 5.1 \\
\hline & GEOFON & $37.00^{\circ}, 28.57^{\circ}$ & $112^{\circ}$ & $41^{\circ}$ & $-76^{\circ}$ & $10 \mathrm{~km}$ & - & 5.3 \\
\hline & This study (InSAR) & $37.1212^{\circ}, 28.6127^{\circ}$ & $92^{\circ}$ & $45^{\circ}$ & $-88^{\circ}$ & $1.8 \mathrm{~km}$ & $1.47 \times 10^{17}$ & 5.4 \\
\hline & This study (regional waveforms) & $37.1009^{\circ}, 28.6146^{\circ}$ & $87^{\circ}$ & $21^{\circ}$ & $-140^{\circ}$ & $1 \mathrm{~km}$ & $9.99 \times 10^{16}$ & 5.3 \\
\hline Acıpayam & GCMT & $37.37^{\circ}, 29.38^{\circ}$ & $321^{\circ}$ & $42^{\circ}$ & $-87^{\circ}$ & $12 \mathrm{~km}$ & $4.04 \times 10^{17}$ & 5.7 \\
\hline 2019-03-20 & USGS W-phase & $37.408^{\circ}, 29.531^{\circ}$ & $326^{\circ}$ & $50^{\circ}$ & $-87^{\circ}$ & $17.5 \mathrm{~km}$ & $4.57 \times 10^{17}$ & 5.7 \\
\hline \multirow[t]{8}{*}{$06: 34: 27$} & USGS body wave & $37.408^{\circ}, 29.531^{\circ}$ & $320^{\circ}$ & $50^{\circ}$ & $-88^{\circ}$ & $6 \mathrm{~km}$ & $2.48 \times 10^{17}$ & 5.5 \\
\hline & USGS RMT & $37.408^{\circ}, 29.531^{\circ}$ & $314^{\circ}$ & $47^{\circ}$ & $-80^{\circ}$ & $12 \mathrm{~km}$ & $4.62 \times 10^{17}$ & 5.7 \\
\hline & GEOFON & $37.46^{\circ}, 29.48^{\circ}$ & $310^{\circ}$ & $45^{\circ}$ & $-99^{\circ}$ & $16 \mathrm{~km}$ & - & 5.7 \\
\hline & Yang et al. (2020) (InSAR) & $37.43^{\circ}, 29.38^{\circ}$ & $332^{\circ}$ & $44^{\circ}$ & $-76^{\circ}$ & $6 \mathrm{~km}$ & - & 5.7 \\
\hline & Elliott et al. (2020) (InSAR) & $37.444^{\circ}, 29.426^{\circ}$ & $336^{\circ}$ & $58^{\circ}$ & $-70^{\circ}$ & $6.1 \mathrm{~km}$ & $3.12 \times 10^{17}$ & 5.6 \\
\hline & This study (InSAR) & $37.4595^{\circ}, 29.4152^{\circ}$ & $326^{\circ}$ & $54^{\circ}$ & $-80^{\circ}$ & $6.1 \mathrm{~km}$ & $3.09 \times 10^{17}$ & 5.6 \\
\hline & This study (teleseismic body waveforms) & $37.4243^{\circ}, 29.4669^{\circ}$ & $328^{\circ}$ & $44^{\circ}$ & $-88^{\circ}$ & $6 \mathrm{~km}$ & $2.44 \times 10^{17}$ & 5.5 \\
\hline & This study (regional waveforms) & $37.4243^{\circ}, 29.4669^{\circ}$ & $324^{\circ}$ & $43^{\circ}$ & $-76^{\circ}$ & $7 \mathrm{~km}$ & $3.49 \times 10^{17}$ & 5.6 \\
\hline Bozkurt & GCMT & $37.81^{\circ}, 29.68^{\circ}$ & $275^{\circ}$ & $35^{\circ}$ & $-94^{\circ}$ & $14.7 \mathrm{~km}$ & $8.27 \times 10^{17}$ & 5.9 \\
\hline 2019-08-08 & USGS W-phase & $37.935^{\circ}, 29.700^{\circ}$ & $289^{\circ}$ & $38^{\circ}$ & $-80^{\circ}$ & $15.5 \mathrm{~km}$ & $7.59 \times 10^{17}$ & 5.9 \\
\hline \multirow[t]{6}{*}{$11: 25: 29$} & USGS body wave & $37.935^{\circ}, 29.700^{\circ}$ & $286^{\circ}$ & $36^{\circ}$ & $-80^{\circ}$ & $9 \mathrm{~km}$ & $5.81 \times 10^{17}$ & 5.8 \\
\hline & USGS RMT & $37.935^{\circ}, 29.700^{\circ}$ & $277^{\circ}$ & $34^{\circ}$ & $-82^{\circ}$ & $10 \mathrm{~km}$ & $5.45 \times 10^{17}$ & 5.8 \\
\hline & GEOFON & $37.91^{\circ}, 29.75^{\circ}$ & $279^{\circ}$ & $33^{\circ}$ & $-95^{\circ}$ & $16 \mathrm{~km}$ & - & 5.9 \\
\hline & This study (InSAR) & $37.8750^{\circ}, 29.6962^{\circ}$ & $270^{\circ}$ & $32^{\circ}$ & $-96^{\circ}$ & $8.5 \mathrm{~km}$ & $9.14 \times 10^{17}$ & 5.9 \\
\hline & This study (teleseismic body waveforms) & $37.8895^{\circ}, 29.6113^{\circ}$ & $254^{\circ}$ & $35^{\circ}$ & $-95^{\circ}$ & $12 \mathrm{~km}$ & $4.46 \times 10^{17}$ & 5.7 \\
\hline & This study (regional waveforms) & $37.8895^{\circ}, 29.6113^{\circ}$ & $283^{\circ}$ & $38^{\circ}$ & $-84^{\circ}$ & $10 \mathrm{~km}$ & $6.43 \times 10^{17}$ & 5.8 \\
\hline
\end{tabular}




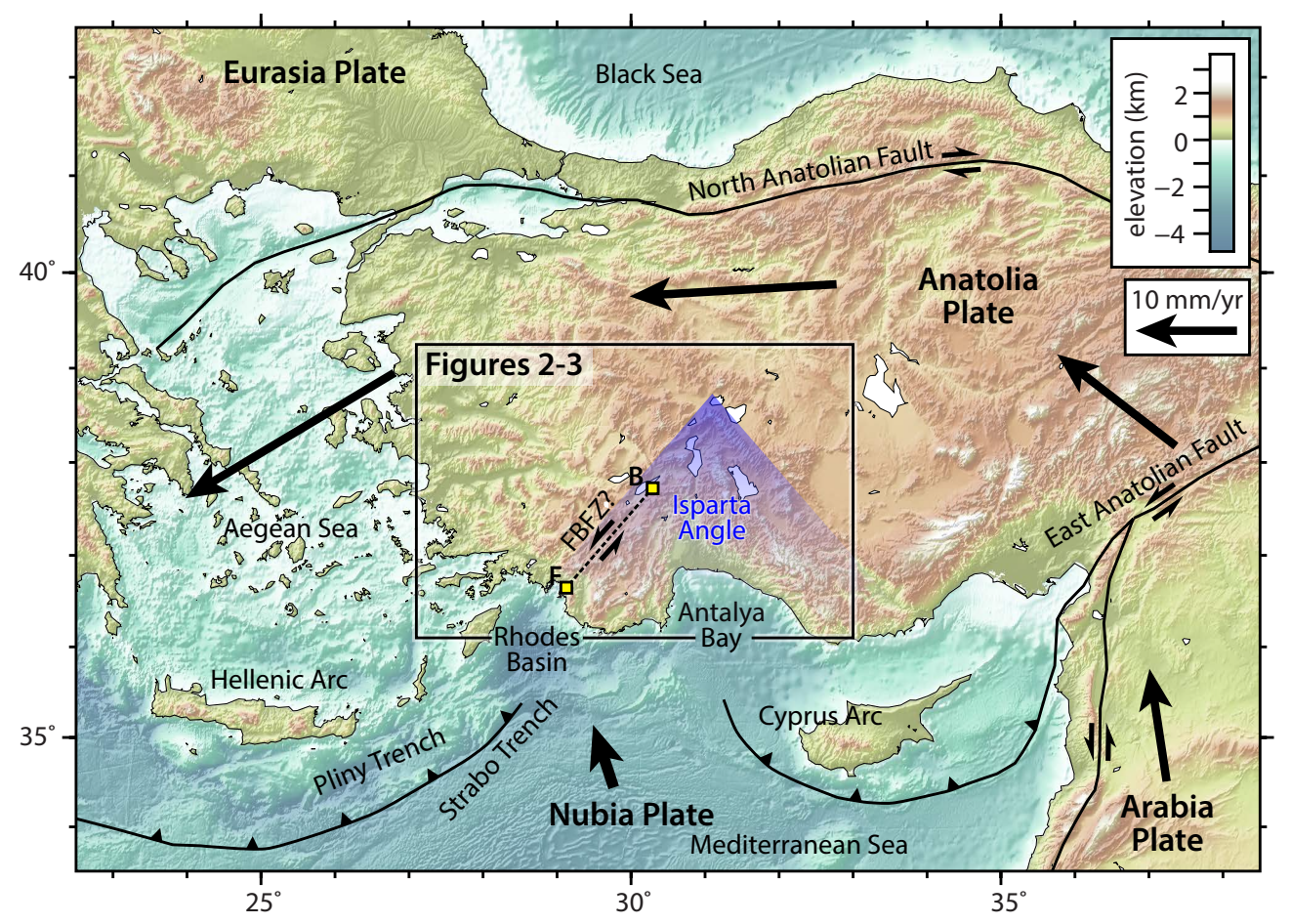

Figure 1. (a) Regional tectonic setting. Black lines show major plate boundary faults and representative motions of the Anatolia, Nubia and Arabia plates with respect to Eurasia are denoted by thick black arrows (Reilinger et al. 2006). The Isparta Angle is shaded in blue and the generalized trend of the purported Fethiye-Burdur Fault Zone (FBFZ) is marked by a dashed line. Yellow squares denote the cities of Fethiye (F) and Burdur (B). 

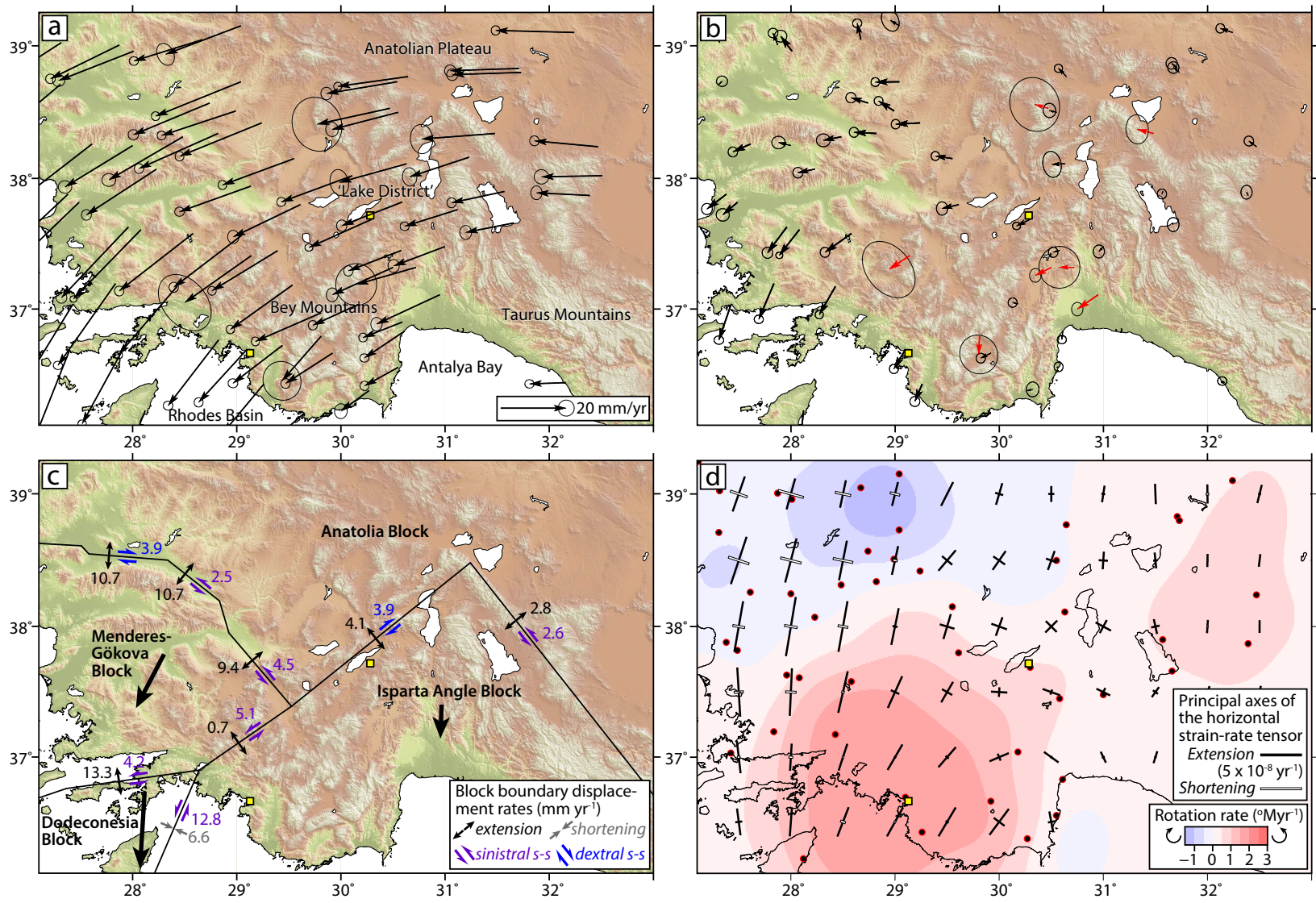

Figure 2. GPS velocities and derived tectonic models for southwestern Turkey (figure adapted from Howell et al. (2017)). Yellow squares are the cities of Fethiye and Burdur and the topography is as in Figure 1. (a) GPS velocities and $2 \sigma$ uncertainties, showing data from Aktug et al. (2009) and Tiryakioğlu et al. (2013) placed into the same fixed Eurasia reference frame (see Howell et al. (2017) for details). (b) GPS velocities with respect to stable Anatolia. Red vectors show stations with large uncertainties that were excluded from Howell et al.'s (2017) analysis. (c) GPS-derived block model boundaries and slip-rates (in $\mathrm{mm} \mathrm{yr}^{-1}$ ) from Tiryakioğlu et al. (2013). Thick black arrows show generalized block motions with respect to Anatolia. (d) GPS-derived strain rate field from Howell et al. (2017). Colours indicate vertical axis rotation rates; bars indicate principal axes of the horizontal strain rate tensor, with extension in black and contraction in white; and black circles show GPS datapoints used in the analysis. 


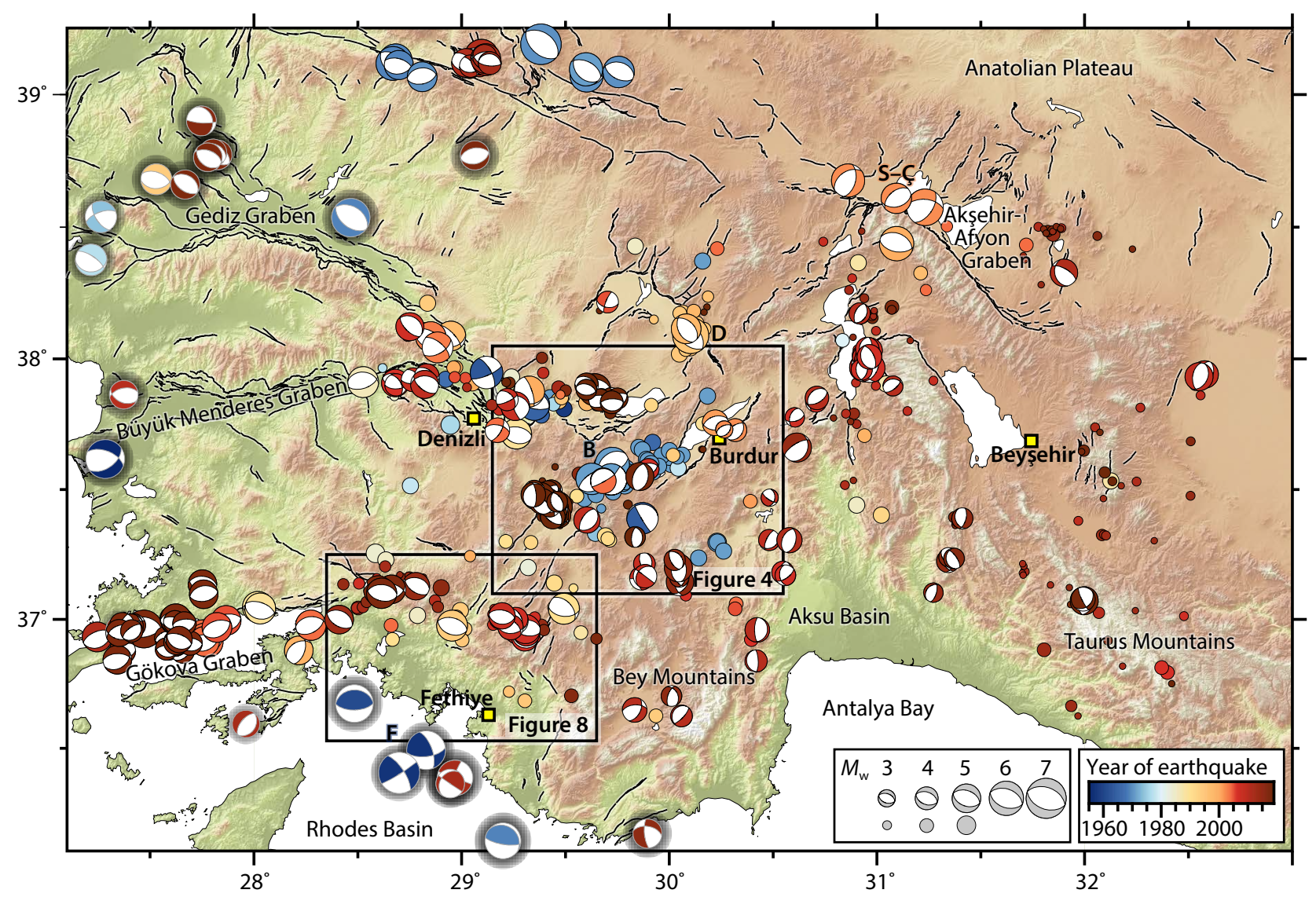

Figure 3. Crustal seismicity and mapped active faults of southwestern Turkey. Active faults are from the database of Emre et al. (2018) and the topography is as in Figure 1. Earthquake focal mechanisms (beach balls) and epicenters (circles) are coloured by year of occurrence and plotted at their relocated epicenters (Karasözen et al. (2016, 2018), and this study), except for a few offshore events which could not be reliably relocated and which are marked with shadows. We only plot earthquakes whose best available focal or centroid depths are $<35 \mathrm{~km}$; a few deeper events, in particular in the Antalya Bay region, are excluded. A few of the largest earthquakes are marked as follows: $F=$ the 1957 Fethiye earthquakes, $\mathrm{B}=$ the 1971 Burdur earthquake, $\mathrm{D}=$ the 1995 Dinar earthquake, S-Ç = the 2000-2002 Sultandağ1-Çay earthquakes. 


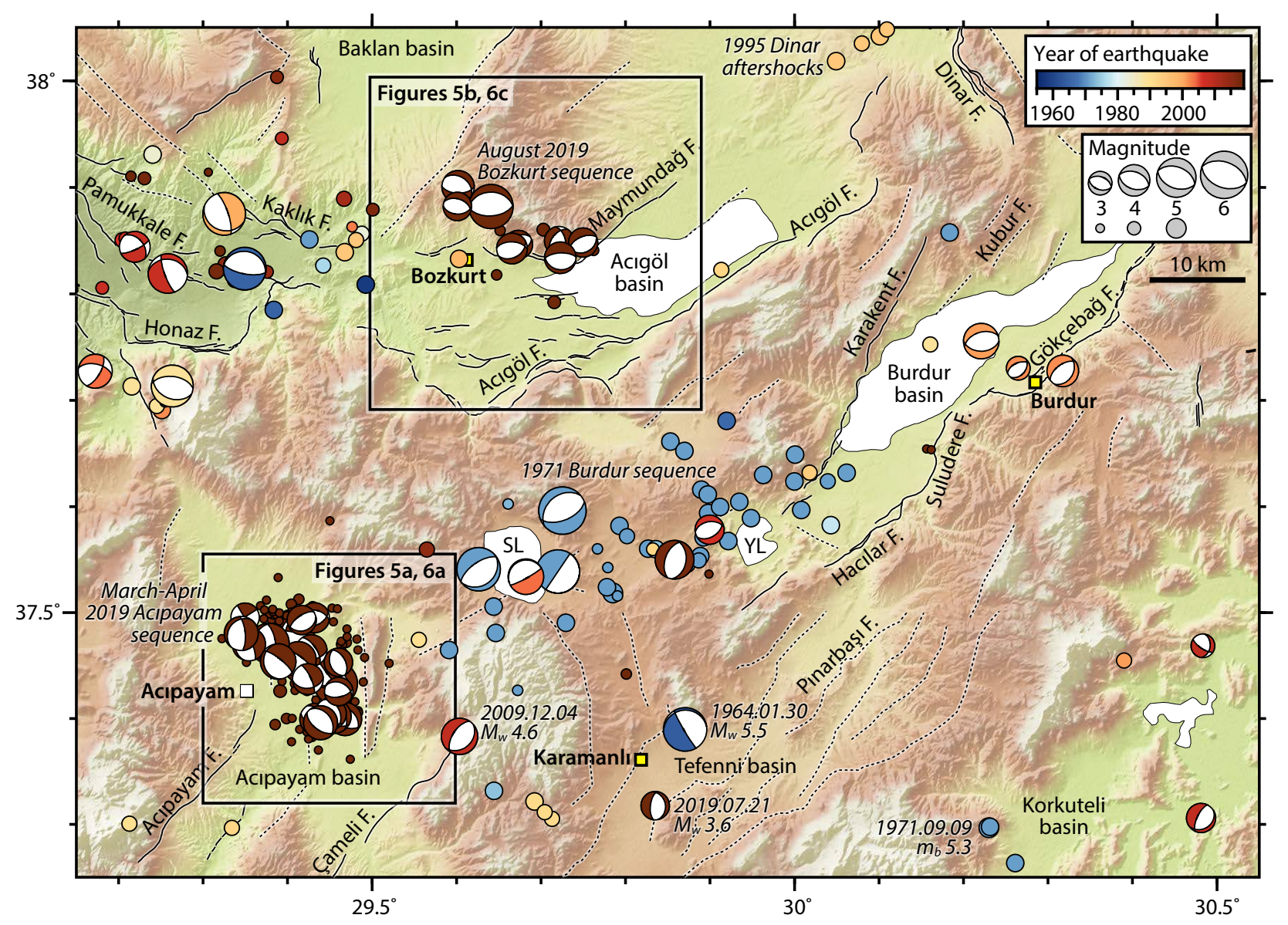

Figure 4. Earthquake mechanisms, epicenters, and mapped active faults in the northern part of the FethiyeBurdur trend. Solid lines show the active fault database of Emre et al. (2018); dashed lines mark a few additional faults from Taymaz \& Price (1992), Alçiçek et al. (2006), Alçiçek et al. (2013), Aksoy \& Aksarı (2016) and Elitez \& Yaltırak (2016). For the 12 May 1971 Burdur mainshock, only the first sub-event is shown; the second has a similar mechanism but its relative location is unconstrained (Taymaz \& Price 1992). $\mathrm{SL}=$ Salda Lake and YL = Yarışlı Lake. 

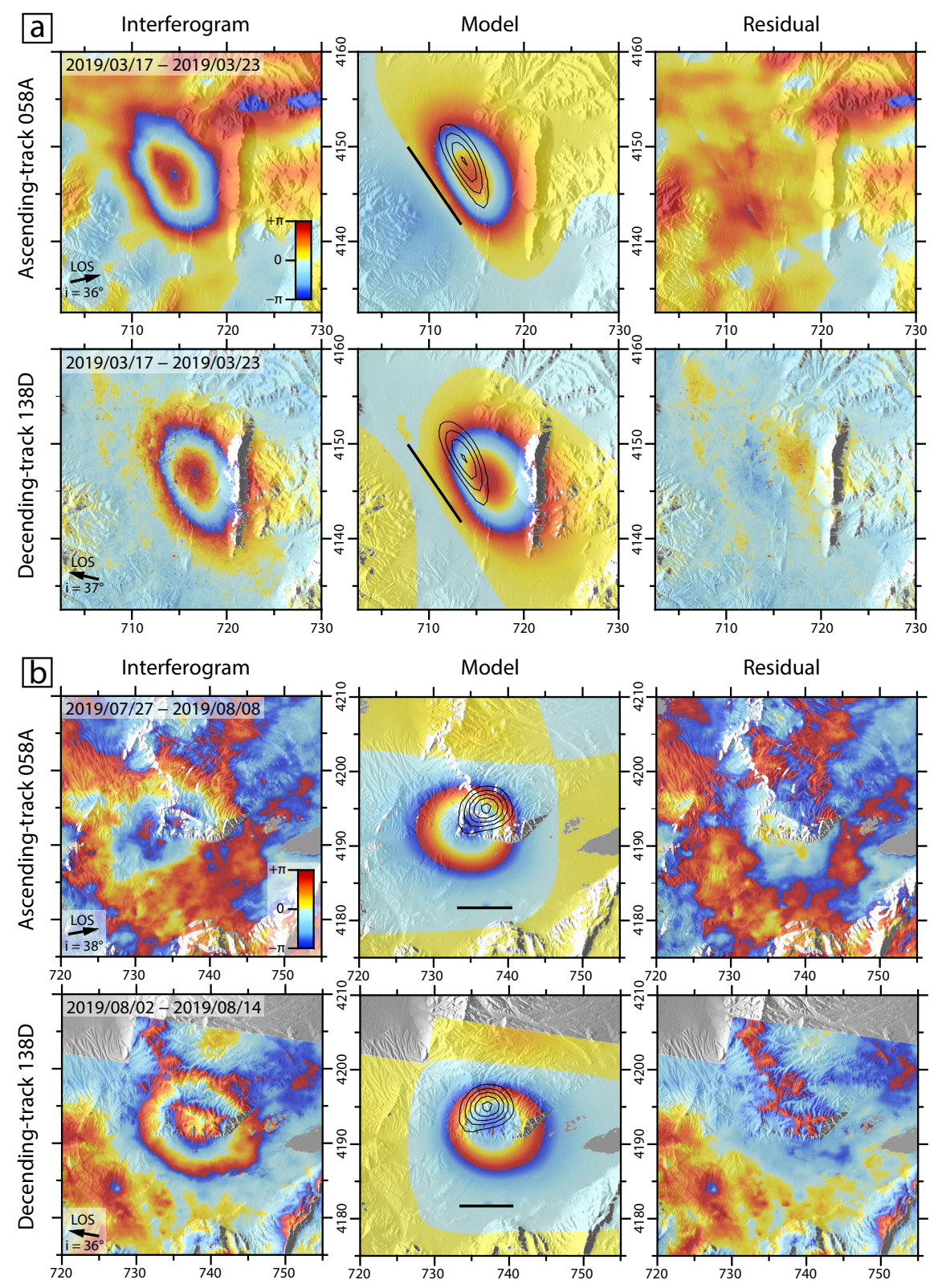

Figure 5. (a) Data (left column), model (center) and residual (right) interferograms for the 20 March 2019 Acıpayam earthquake on ascending track 58A (upper row) and descending track 138D (lower row). Coordinates are UTM Zone 35 kilometers and the InSAR imagery is plotted over artificially-shaded topography. LOS is the satellite line-of-sight, $i$ is the off-nadir incidence angle in the region of interest, and $2 \pi$ radians in phase change is equivalent to $2.77 \mathrm{~cm}$ of deformation relative to the satellite. In the model panels, the contours show $8 \mathrm{~cm}$ slip increments on the buried model fault plane and the thick black line shows its surface projection. (b) Data, model and residual interferograms for the 8 August 2019 Bozkurt earthquake. The layout is the same as in (a), except that the slip contours in the model interferograms are at $12 \mathrm{~cm}$ increments. 

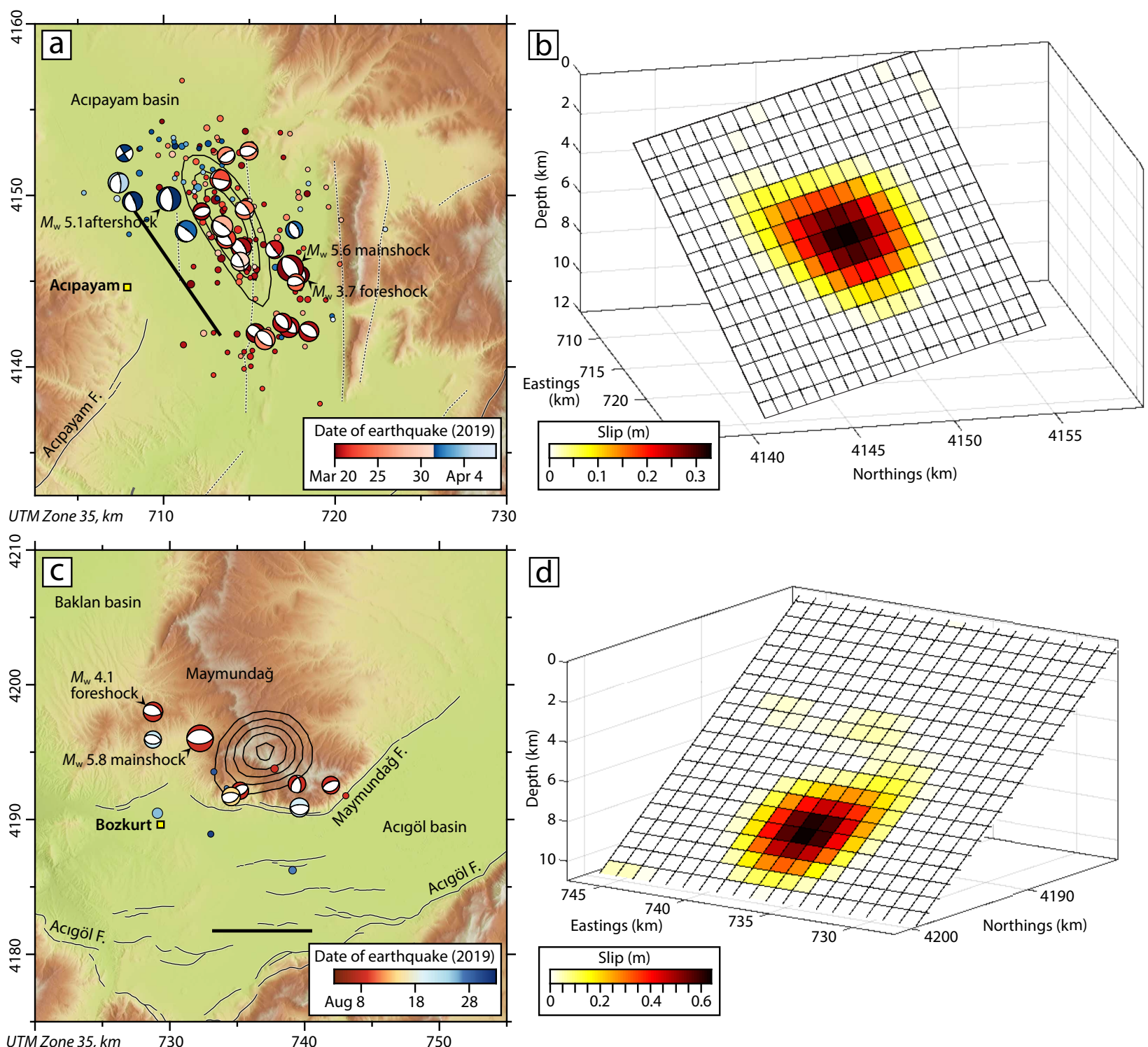

Figure 6. (a) Relocated epicenters and focal mechanisms of the March-April 2019 Acipayam sequence. Events are coloured by date, with those occurring before the largest $\left(M_{w} 5.1\right)$ aftershock in shades of red and those after it in shades of blue. Contours show $8 \mathrm{~cm}$ slip increments on the buried model fault plane and the thick black line shows its surface projection. Thinner solid lines are active faults from Emre et al. (2018) and dashed lines are additional faults from Alçiçek et al. (2006) and Elitez \& Yaltırak (2016). (b) InSAR model slip distribution of the 20 March 2019 Acıpayam mainshock. (c) Relocated epicenters and focal mechanisms of the August 2019 Bozkurt sequence, coloured by date. The layout is the same as in (a), except that contours show $12 \mathrm{~cm}$ slip increments. (d) InSAR model slip distribution of the 8 August 2019 Bozkurt mainshock. 


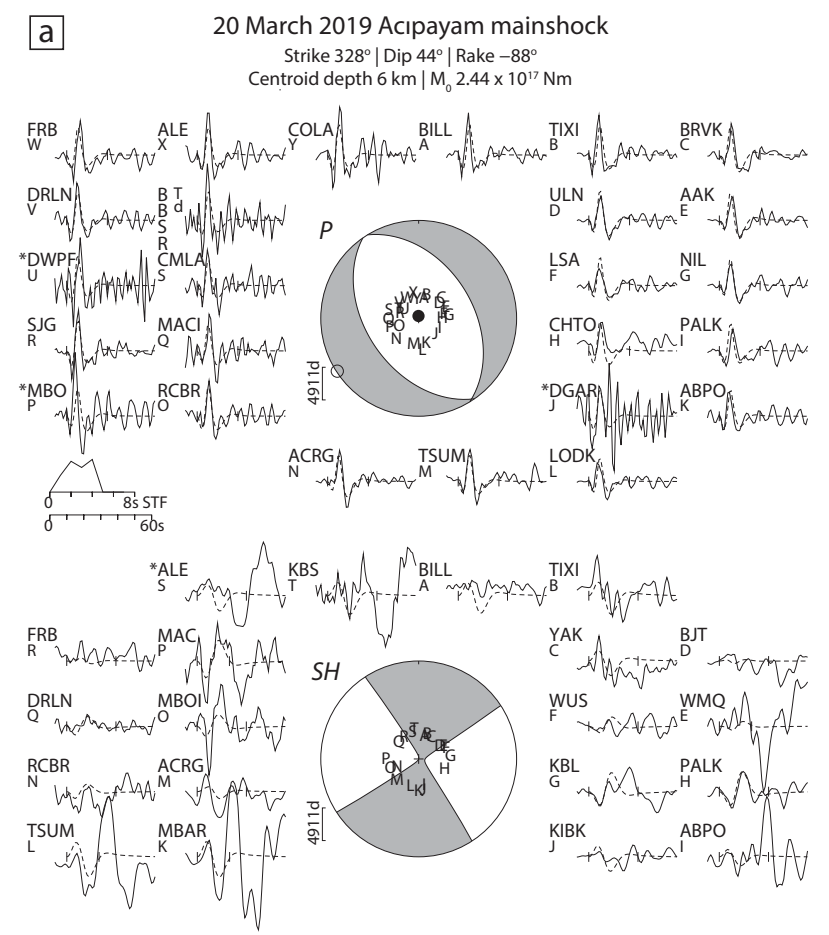

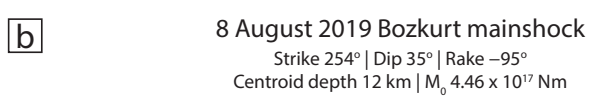
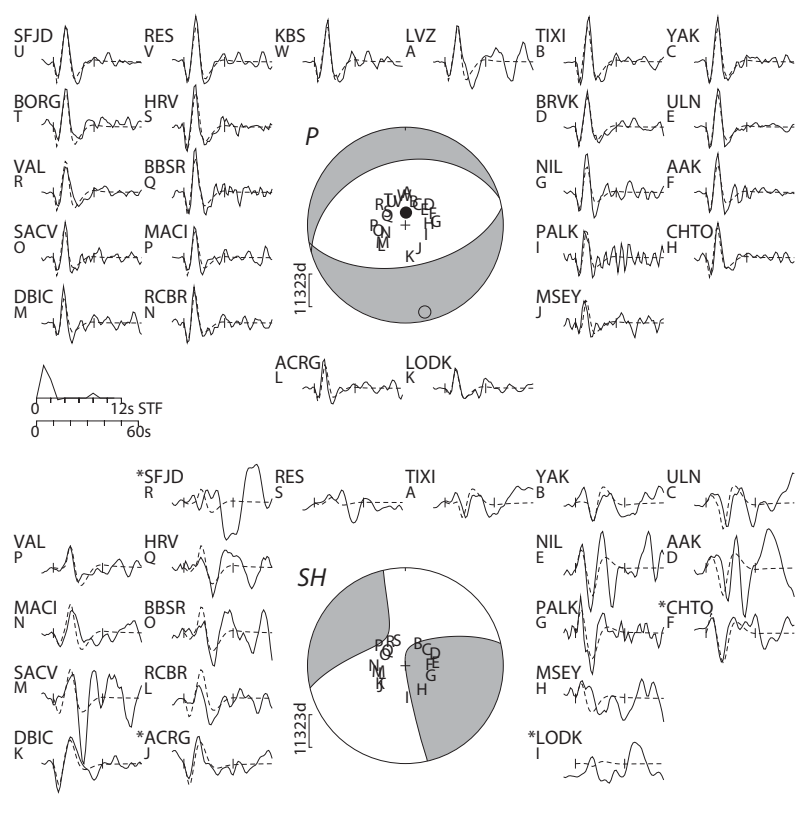

Figure 7. Summaries of our long period teleseismic body waveform models for (a) the 20 March 2019 Acipayam mainshock and (b) the 8 August 2019 Bozkurt mainshock. The upper part of each panel shows the $P$ focal sphere and vertical component seismograms, the lower part shows the $S H$ focal sphere and transverse component seismograms, and the source-time function and a waveform time scalebar are shown on the left. On each focal sphere, we plot nodal planes (lines), station positions (capital letters), and $\mathrm{P}$ and $\mathrm{T}$ axes (solid and open circles). Outside the focal sphere, we plot observed (solid) and synthetic (dashed) seismograms, with station codes and focal sphere station position letters to the left of each. Stations with asterisks are considered too noisy to be included in the inversion, but are shown for reference. Vertical ticks mark the $P$ or $S H$ arrival time and the inversion window end. 


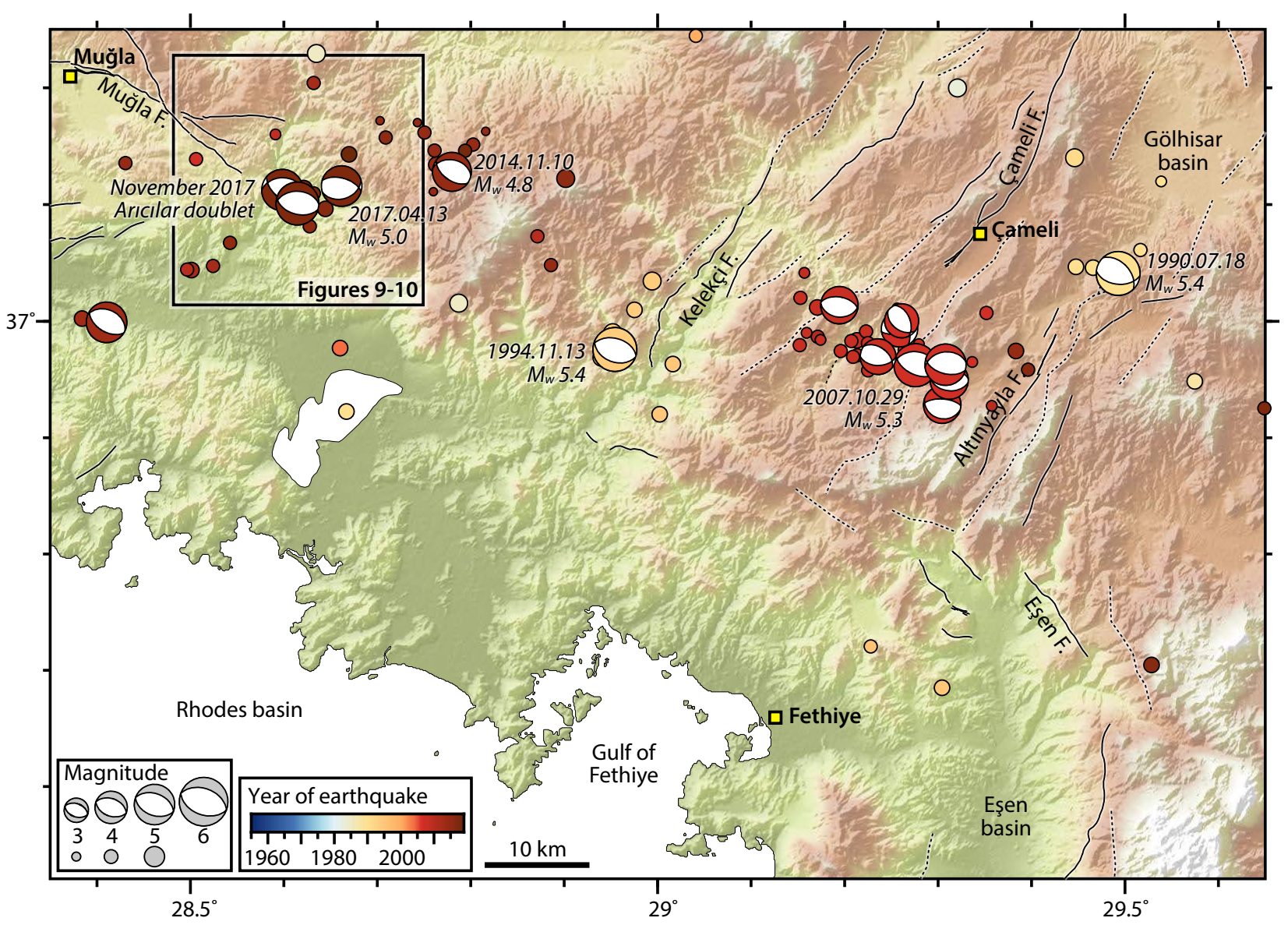

Figure 8. Earthquake mechanisms, epicenters, and mapped active faults in the southern part of the FethiyeBurdur trend. Earthquakes and as in Figure 3 and topography is as in Figure 1. Solid lines show the active fault database of Emre et al. (2018); dashed lines mark a few additional faults from Alçiçek et al. (2006) and Alçiçek (2007). 


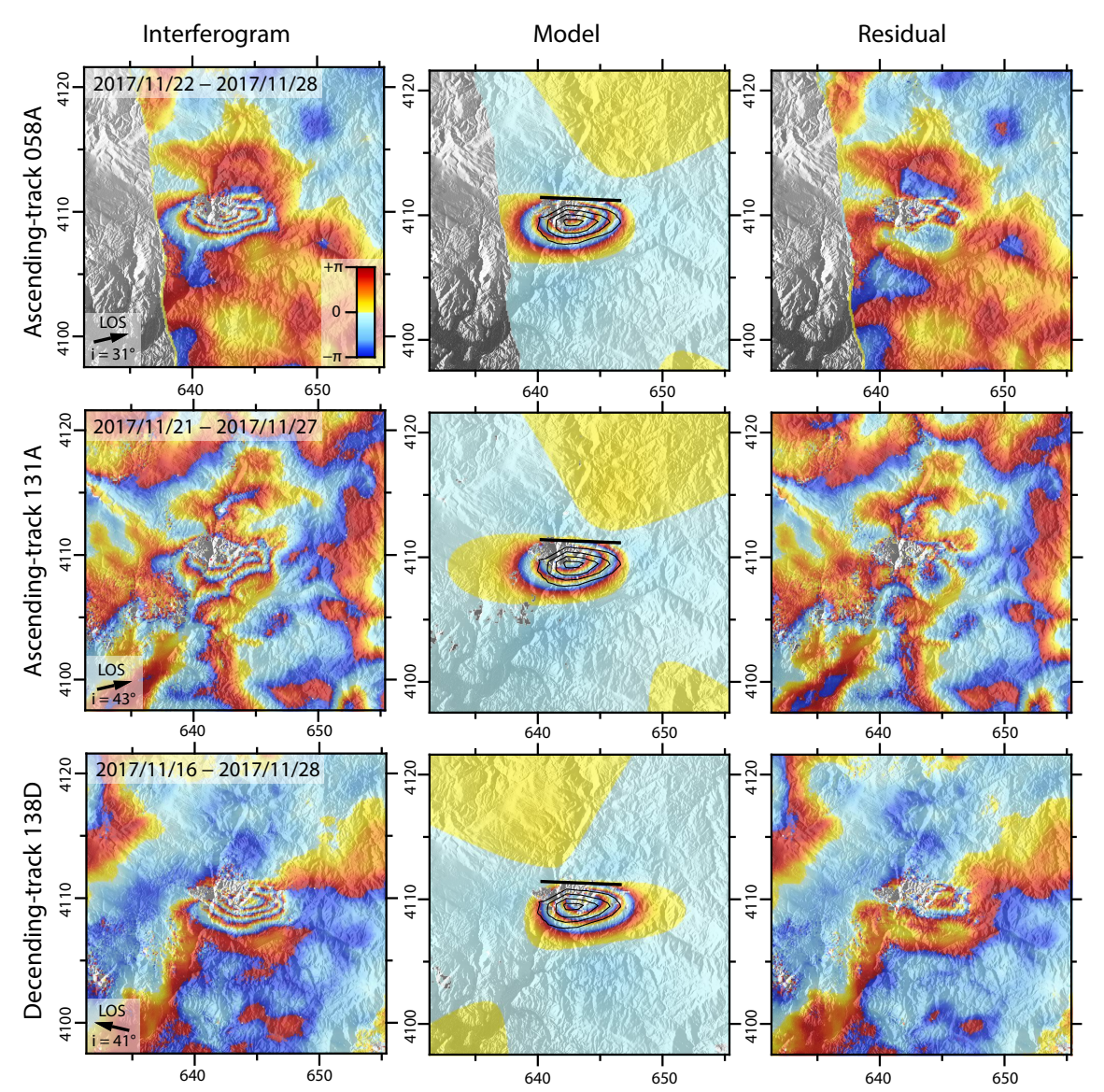

Figure 9. (a) Data (left column), model (center) and residual (right) interferograms for the 24 November 2017 Arıcilar earthquake on ascending track 58A (upper row), ascending track 131A (middle row), and descending track 138D (lower row). The layout is the same as for Figure 5, with $8 \mathrm{~cm}$ model slip contours. 


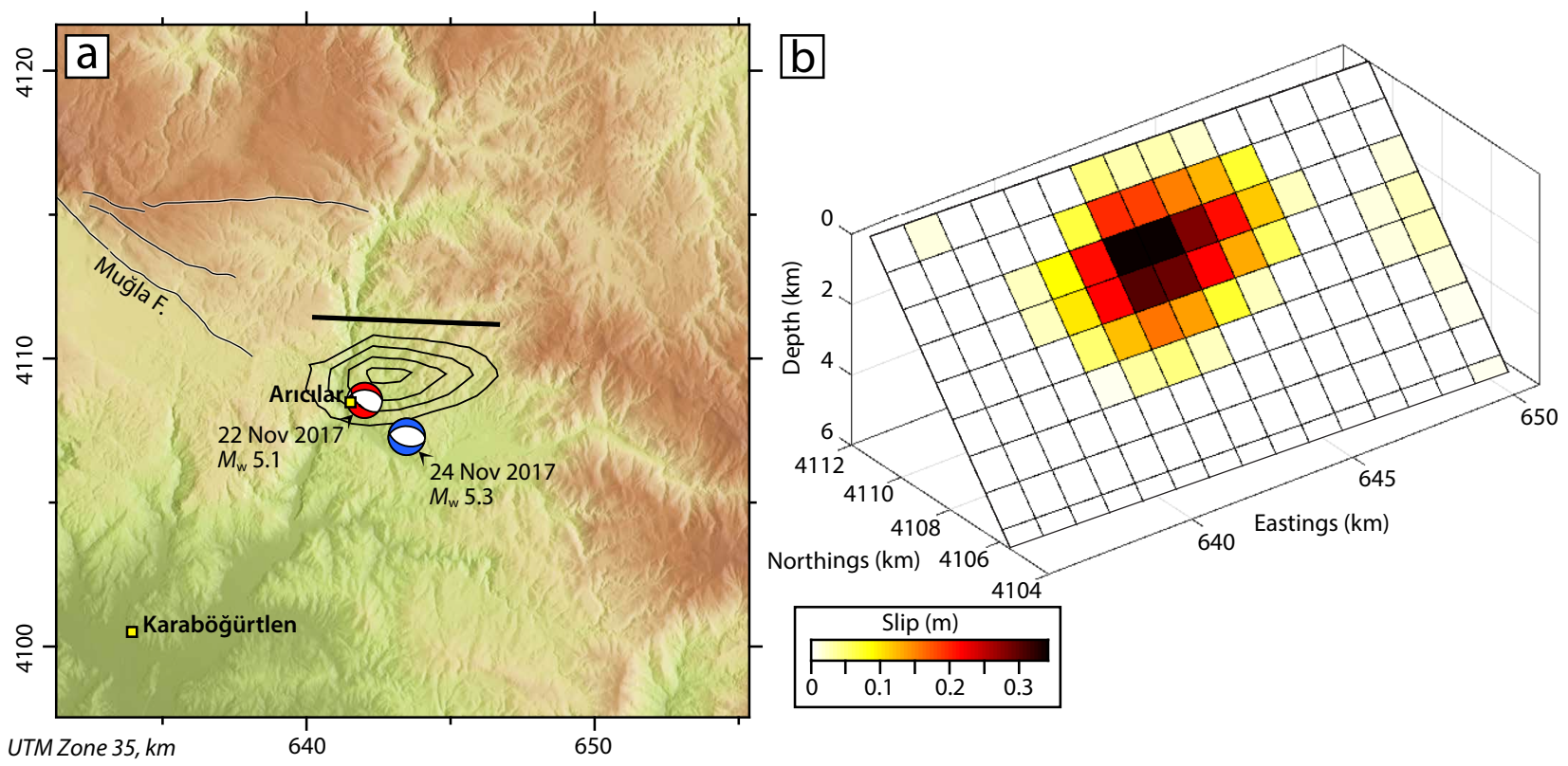

Figure 10. Relocated epicenters and focal mechanisms of the 22 November Arıcılar foreshock (red) and the 24 November 2017 mainshock. Contours show $8 \mathrm{~cm}$ slip increments on the buried model fault plane and the thick black line shows its surface projection. Other active faults are from Emre et al. (2018) and topography is as in Figure 1. (b) InSAR model slip distribution of the Arıcılar earthquake. 